\title{
The Design of Fiscal Adjustment Strategies in Botswana, Lesotho, Namibia, and Swaziland
}

Olivier Basdevant, Dalmacio Benicio, Borislava Mircheva, Joannes Mongardini, Geneviève Verdier, Susan Yang, and Luis-Felipe Zanna 


\title{
IMF Working Paper
}

\section{African and Research Departments}

\author{
The Design of Fiscal Adjustment Strategies \\ in Botswana, Lesotho, Namibia, and Swaziland
}

\section{Prepared by Olivier Basdevant, Dalmacio Benicio, Borislava Mircheva, Joannes Mongardini, Geneviève Verdier, Susan Yang, and Luis-Felipe Zanna}

\author{
Authorized for distribution by Andy Berg and Calvin A. Mc Donald
}

November 2011

\section{This Working Paper should not be reported as representing the views of the IMF. The views expressed in this Working Paper are those of the author(s) and do not necessarily represent those of the IMF or IMF policy. Working Papers describe research in progress by the author(s) and are published to elicit comments and to further debate.}

\begin{abstract}
Botswana, Lesotho, Namibia, and Swaziland face the serious challenge of adjusting not only to lower Southern Africa Customs Union (SACU) transfers because of the global economic crisis, but also to a potential further decline over the medium term. This paper assesses options for the design of the needed fiscal consolidation. The choice among these options should be driven by (i) the impact on growth and (ii) the specificities of each country. Overall, a focus on government consumption cuts appears to minimize the negative impact on growth, and would be appropriate given the relatively large size of the public sector in each country.
\end{abstract}

JEL Classification Numbers: C63, E62, H60

Keywords: Fiscal adjustment, fiscal multipliers, SACU transfers

Authors’ E-Mail Address: obasdevant@imf.org; dbenicio@imf.org; bmircheva@imf.org; jmongardini@imf.org; gverdier@imf.org; syang@imf.org; fzanna@imf.org 


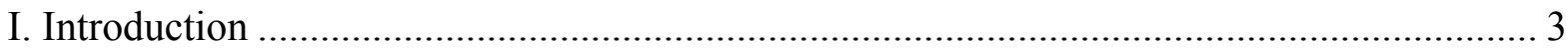

II. Designs for a Successful Fiscal Consolidation .......................................................... 5

A. Fiscal Consolidation and Multipliers ............................................................... 5

B. Factors of a Successful Fiscal Consolidation.............................................................. 6

III. A Dynamic Model with Demand and Supply Effects ............................................... 9

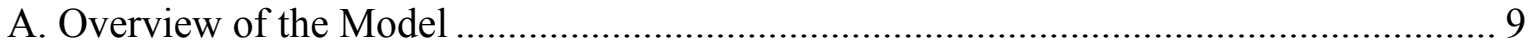

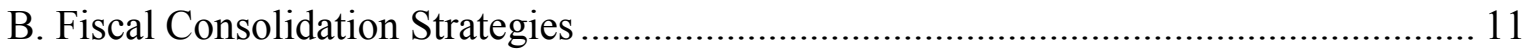

IV. Economics of Single-Instrument Fiscal Consolidations to SACU Transfer Reductions . 13

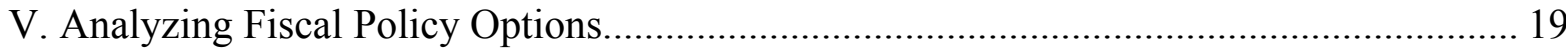

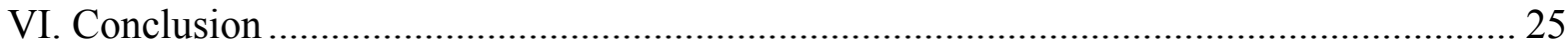

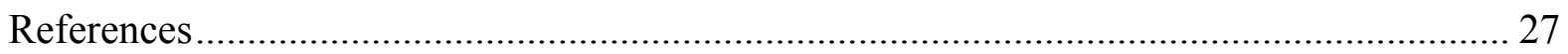

Box

1. SACU Revenue Sharing Formula ....................................................................... 4

Figures

1. Wage Bill in Sub-Saharan Africa, 2005-10 .............................................................. 7

2. Impact of Government Consumption Adjustment for Namibia, in Response to a

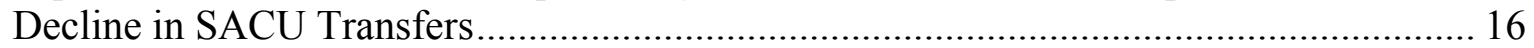

3. Comparison of the Different Single-Instrument Adjustment Strategies for Namibia ........ 17

4. Cross-Country Comparison of Different Single-Instrument Fiscal Consolidations

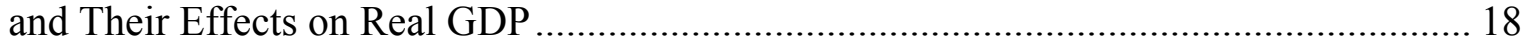

5. GDP Response to Different Policy Instruments ........................................................... 23

6. Current Account Balance Response to Different Policy Instruments............................... 24

Tables

1. SACU Transfers in BLNS and Simulated Loss ......................................................... 3

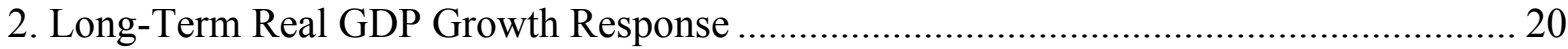

3. Multiplier Across Different Fiscal Consolidation Strategies........................................ 22

Appendixes

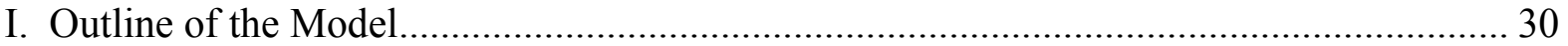

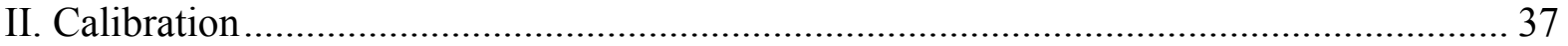




\section{INTRODUCTION}

1. Botswana, Lesotho, Namibia, and Swaziland (BLNS) face significant risks of a permanent loss of revenue from the Southern Africa Customs Union (SACU). They already experience a sharp loss in 2010/11-11/12, in the context of the global crisis. However BLNS could also face a further decline over the medium term, related to at least three structural factors: (i) a change in the SACU revenue-sharing formula currently under discussion (Box 1) (ii) a reduction in the common external tariff rates as a result of trade liberalization, and (iii) the creation of the Southern African Development Community (SADC) customs union. Quantifying with precision these risks is a daunting task, but under the preliminary parameters under discussion on the revenue sharing formula, and the impact on trade liberalization, the baseline estimate of the fall in SACU transfers ranges, for BLNS, from 5 percent of GDP to 15 percent (Table 1). From these parameters it is possible to define options for a fiscal adjustment, which is the purpose of this paper. Although the specific magnitude of each shock is yet unknown, the results are nevertheless qualitatively robust to this magnitude. Thus, the policy recommendations would remain broadly the same, even if the size of the needed fiscal adjustment were to be smaller. ${ }^{1}$

Table 1. SACU Transfers in BLNS and Simulated Loss

\begin{tabular}{|c|c|c|c|}
\hline \multicolumn{4}{|c|}{ (Percent of GDP) } \\
\hline & \multicolumn{2}{|c|}{ Levels } & Simulated loss \\
\hline & $2005 / 6-8 / 9$ & $2009 / 10-12 / 13$ & \\
\hline Botswana & 9.1 & 7.8 & -5.0 \\
\hline Lesotho & 34.2 & 21.9 & -6.7 \\
\hline Namibia & 10.9 & 9.1 & -5.0 \\
\hline Swaziland & 23.5 & 14.8 & -15.0 \\
\hline
\end{tabular}

Source: Country authorities and IMF staff simulations.

\section{The challenge is both fiscal and external, because the higher SACU revenue also} provided foreign exchange to finance imports. BLNS have no recourse to exchange rate policy, because the BLNS currencies are pegged to the rand (a crawling peg in the case of Botswana and parity for the others). ${ }^{2}$ Correspondingly, the ability to use monetary policy actively is limited by the need to defend the pegs. Fiscal policy then becomes the main macroeconomic tool to respond to the loss of transfers. However, BLNS also face significant development challenges (e.g., widespread poverty, HIV/AIDS), a relatively large public sector, and high unemployment. As a result, the design of their fiscal adjustment strategies has to focus not only on the immediate goal of rebalancing public finances, but also on restoring external stability while maintaining positive prospects for medium-term growth.

\footnotetext{
${ }^{1}$ The policy response was also analyzed in the companion paper of Mongardini and others (2011).

${ }^{2}$ See Wang and others (2007), which discusses the Common Monetary Area under which Namibia, Lesotho, and Swaziland peg their currency to the rand.
} 


\section{This paper provides guidance on how to design the needed fiscal consolidation}

plans. To do so, it first reviews past experiences of successful fiscal consolidations (Section II), and then it uses a dynamic stochastic general equilibrium (DSGE) model with country-specific calibrations (Section III) to simulate the impact of various policy options on growth. Fiscal strategies are ranked according to the magnitude of the impact on growth. The choice of a fiscal consolidation plan should, however, not be based on the individual merit of each instrument, as single-based instrument strategies are not always feasible — or desirable - in practice (Section IV). Instead, the strategy could focus on multiple instruments (Section V). The conclusion provides some recommendations along these lines (Section VI).

\section{Box 1. SACU Revenue Sharing Formula}

SACU revenue is composed of customs duties (C) and excises (E). According to the 2002 agreement, the revenue is shared following three components:

- Customs revenue is distributed on the basis of intra-SACU imports.

- Eighty-five percent of excise revenue is distributed on the basis of members' GDP.

- Fifteen percent of excise revenue is distributed equally through a development fund, with an adjustment of a small portion inversely proportional to the member's GDP.

The revenue sharing formula is:

$$
R_{i}=a_{i} C+0.85 y_{i} E+0.15_{\frac{1}{5}}^{1} E\left(1-\frac{h_{i}-1}{10}\right)
$$

For each country $\mathrm{i}, a_{i}$ is the c.i.f. value at the border of imports of the country from all other SACU members, less re-exports, divided by the c.i.f. value of imports less re-exports for all SACU countries; $y_{i}$ is the share of GDP of the country in the SACU GDP; and $h_{i}$ the level of GDP per capita in the country divided by the average across SACU members.

The impact of the import decline on SACU revenue has been larger for the smaller members of the union. The decline in customs revenue implies a smaller common revenue pool to be shared across SACU members. This will affect the smaller SACU members the most, given the importance SACU transfers have in percent of total revenue and of GDP in BLNS, particularly Lesotho and Swaziland. The decline in excises, however, will have a smaller negative effect on smaller SACU members. It will partly be mitigated by the development component of the revenuesharing formula. Overall, the effect of these two elements makes for a highly procyclical revenuesharing formula for BLNS. The revenue gains during the boom period of 2004/05-2007/08 will now be partially reversed and require a significant fiscal adjustment to maintain fiscal and debt sustainability. 


\section{Designs for a SuCCESSful Fiscal Consolidation}

\section{In the design of their fiscal consolidation plan, BLNS can benefit from cross-} country experiences. Two main elements can be emphasized. First, some large fiscal consolidation plans have had limited negative or positive impact on growth (Section II.A). Indeed, policy choices have an impact on fiscal multipliers through the response of the private sector and/or the overall productivity of the economy (e.g., through public investment decisions). Second, a suitable design of fiscal consolidation needs to be complemented by institutional conditions that favor a successful implementation (Section II.B). For example, a strong public financial management system is essential for ensuring that budget execution is in line with the approved budget, and beyond that with the overall fiscal consolidation plan.

\section{A. Fiscal Consolidation and Multipliers}

\section{The empirical literature finds that fiscal multipliers tend to be small, and sometimes even negative, for emerging and developing countries. ${ }^{3}$ The survey by} Spilimbergo, Symansky, and Schindler (2009) reports that fiscal multipliers in developing and emerging economies are between -0.2 and 0.4. Using World Bank lending data for 29 aid-dependent, low-income countries from 1985 to 2009, Kraay (2010) estimates that the output multiplier for government spending ranges between 0 and 0.4 . However, the estimates are rarely statistically significant. Based on quarterly data of government spending, Ilzetzki, Mendoza, and Vegh (2010) find that the cumulative, long-run multiplier for 24 developing countries is 0.18 . Overall this evidence contrasts with estimates for high-income countries, which cover a larger spectrum and are usually higher. ${ }^{4}$

6. Fiscal consolidations are usually contractionary in the short term but can lead to limited GDP losses over the medium term, which explains why multipliers can be small (Tsibouris and others, 2006). In general, fiscal consolidations lead to growth slowdowns (IMF, 2010c; Guajardo, Leigh, and Pescaroti, 2011). In the short run, the impact is driven by a contraction of aggregate demand. This contraction may reflect lower government spending as well as lower private demand once taxes increase. In addition, fiscal consolidations can have a negative medium-term impact on growth to the extent that they may lower public investment in infrastructure and/or human capital. Nevertheless, fiscal consolidations can also have a positive impact on growth. They can induce lower interest rates, lower spreads (through strengthening confidence), and lower debt levels. All of these can induce crowdingin of private consumption and investment which affects GDP positively. Moreover by

\footnotetext{
${ }^{3}$ Fiscal multiplier is defined as the overall impact on growth of a change in a particular fiscal policy instrument (e.g., a change in VAT rates).

${ }^{4}$ Perotti (2005) estimates small positive or even negative numbers in OECD countries, while tax and spending multipliers in the United States are found to be significantly above 1 in Romer and Romer (2010) and Romer and Berstein (2009) respectively.
} 
lowering wages ${ }^{5}$ and prices and by inducing real exchange- rate depreciation, fiscal consolidations may improve competitiveness and therefore spur growth. Finally, fiscal consolidations can have a positive impact when they are associated with cutting unproductive spending (Gupta and others, 2005). Alternatively, they can create an occasion to reallocate public spending, by increasing the share of development spending (i.e., investment in human capital and infrastructure), which has a positive impact on long-term growth.

\section{B. Factors of a Successful Fiscal Consolidation}

\section{Longer fiscal consolidations can increase the probability of halting the} adjustment before its completion (von Hagen, Hallett, and Strauch, 2001; Tsibouris and others, 2006). The empirical evidence shows that there is, overall, a broad balance between upfront and gradual successful adjustments (Tsibouris and others, 2006). However, large fiscal consolidations, especially in emerging and low-income countries, have tended to be more front-loaded (Tsibouris and others, 2006; Kumar, Leigh, and Plekhanov, 2007). Frontloading is important for two main reasons: (i) to reassure markets and international partners, especially when fiscal sustainability is at risk, and (ii) to benefit from strong political and social support, which is more easily gathered in periods of "economic emergency." While BLNS may need to phase the adjustment over several years (e.g., Swaziland is already engaged in a three-year fiscal consolidation under its own Fiscal Adjustment Roadmap), the sustainability of the adjustment would still suggest responding to a permanent shock with upfront, permanent and large measures to shorten the adjustment period and to avoid reform fatigue.

8. The revenue-expenditure mix of the fiscal consolidation needs to reflect the country's main fiscal risks. The adjustment should rely on spending cuts in an oversized public sector and on revenue-boosting measures where tax collection is low (IMF 2010a). ${ }^{6}$ On the expenditure side, adjustments have usually addressed either immediate risks, which are associated with cuts in recurrent spending, or future risks, which generally relate to health spending and population growth (HIV/AIDS, pension reform, healthcare reform). On the revenue side, measures have typically focused on reducing tax expenditures and increasing tax rates to levels comparable to regional features, while tax administration reforms have focused on a risk-based taxpayer compliance strategy.

\section{BLNS face both revenue and expenditure problems, with a stronger fiscal risk} on the expenditure side. They all have large wage bills (Figure 1) that warrant reducing government spending, not only to improve fiscal balances but also to provide more incentives

\footnotetext{
${ }^{5}$ To the extent that private wages are indeed linked to public wages, or that the public sector represents a large portion of the economy.

${ }^{6}$ Revenue measures have often been found more prominent for emerging and developing economies, which typically start from a low revenue-to-GDP ratio (Gupta and others, 2003; Ardagna, 2004).
} 
to work in the private sector and reduce reservation wages. Additionally, the quality of spending is questionable, owing to weaknesses in budget preparation and expenditure controls, suggesting that cuts could be identified in unproductive spending. Moreover, some countries face revenue issues: first, under the assumption of a medium-term fall in external revenue (SACU transfers, but also mineral revenue in Botswana and Namibia); second, tax exemptions (Lesotho, Swaziland), and finally a low voluntary compliance rate (all of BLNS). On the latter two, the authorities of each country have already taken significant steps, either by removing tax exemptions (Swaziland submitted a law to that effect in June 2011), or by taking steps to reform tax administration according to a modern structure based on selfassessment and incentives for voluntary tax compliance (Botswana, Lesotho, Swaziland). ${ }^{7}$ Overall, a key challenge is to address potentially significant fall in SACU transfers and relatively high spending.

Figure 1. Wage Bill in Sub-Saharan Africa, 2005-10

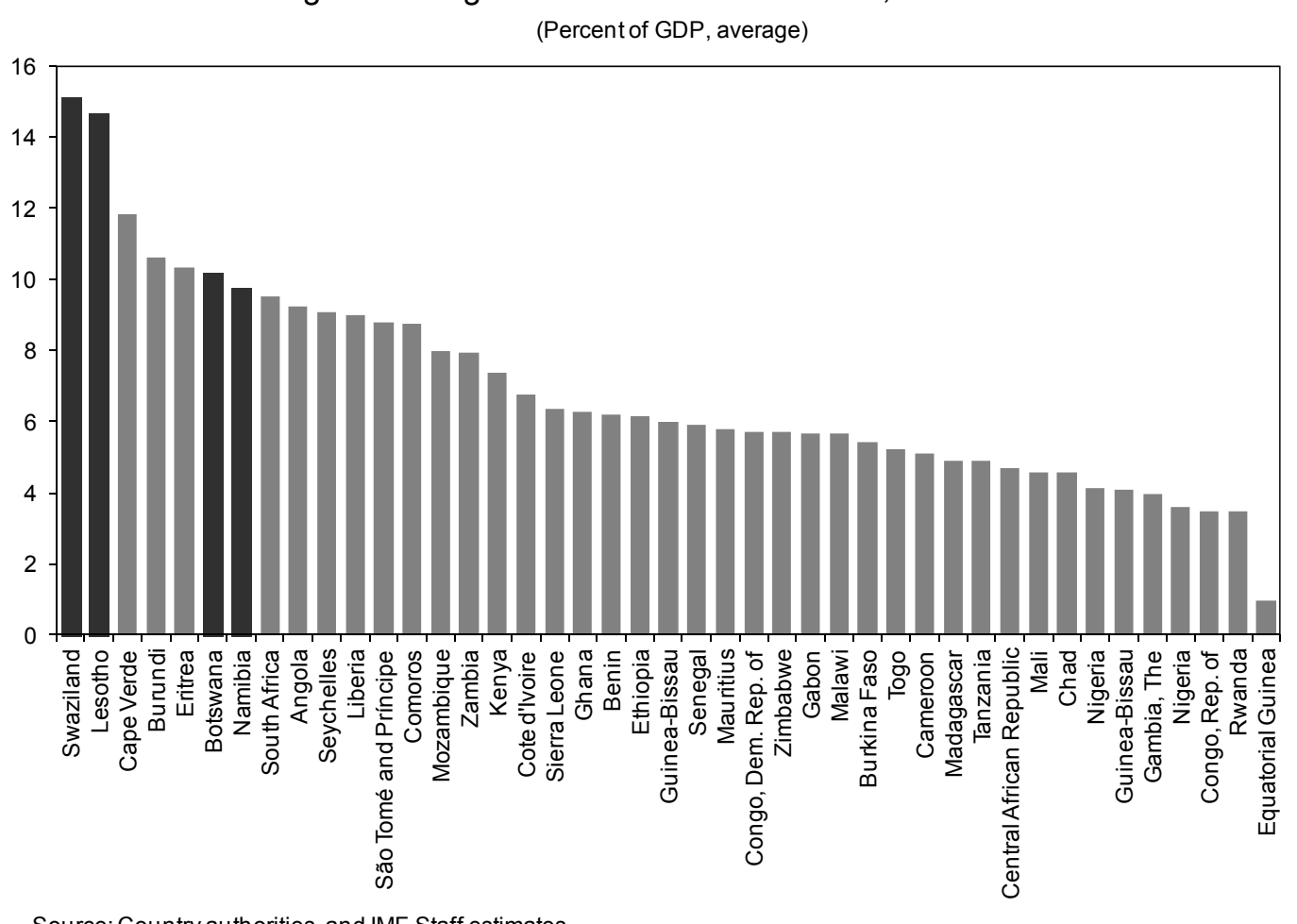

10. Many successful adjustment plans use contingencies to build space to cope with potential adverse shocks (Mauro, 2011). ${ }^{8}$ Such planning could be quite significant. For 66 plans reviewed in Mauro (2011), the average annual planned improvement in the fiscal

\footnotetext{
${ }^{7}$ However, tax administration improvements, while essential, would not generally provide short-term gains (Russell, 2010).

${ }^{8}$ Contingency measures could also cover positive surprises, such as a higher growth outturn.
} 
balance was about $1 \frac{1}{2}$ percent of GDP. However, the execution led to an improvement of only about 1 percent of GDP. The discrepancy was not related to the size of the adjustment, but instead to spending cuts that did not materialize. As a result, additional revenue measures were often taken to compensate for the difficulty in implementing spending cuts, thus improving the revenue outturn.

11. Fiscal consolidations require transparency and simplicity. Fiscal consolidations, particularly large ones, require strong support from all economic agents. The objective of the adjustment has to be simple and well understood. This facilitates transparency and accountability and ultimately strengthens the case for political consensus on the adjustment. Broad support from the population and budget agencies is a key determinant of successful fiscal consolidations (Mauro, 2011). A priority for BLNS is therefore to build public support through communication campaigns. These would educate the public about the scale of fiscal challenges and explain what reasonably can be achieved through reforms without overburdening taxpayers or unduly curtailing necessary public services.

12. Public wage policy will play a major role in BLNS in restoring external balances. With the loss of foreign exchange, the decline in SACU revenue implies that the real exchange rate needs to depreciate. However, with the fixed exchange rate, this depreciation risks requiring a large economic contraction to produce the required decline in real wages. Fiscal consolidation reduces the size of the needed real depreciation. It thus mitigates the effect from the loss of foreign exchange, which would otherwise fall entirely on the private sector. If public sector wages were to stay constant or rise, it would be much more difficult to achieve the required real depreciation. This would be aggravated further by the extent to which public and private wages are linked. Higher public sector wages tend to increase the scale of the needed real exchange rate adjustment.

\section{Strong budget institutions, such as medium-term frameworks and fiscal rules} are essential to a successful fiscal consolidation (IMF, 2010b). The adjustment could rely on a medium-term strategy, underpinned by a medium-term expenditure framework, which anchors budget preparation. ${ }^{9}$ Procedures for budget elaboration and implementation would also require strong buy-in from parliament and other stakeholders. Fiscal consolidations would ideally cover the general government to reduce the risk of increasing contingent liabilities in other government agencies. The burden would need to be shared, especially to avoid excessive fiscal pressure on one specific body of the general government. Numerical and procedural fiscal rules tend to be associated with successful adjustments. The crosscountry statistical analysis finds that the intensity of national fiscal rules is positively associated with the extent to which targets were met (IMF, 2005; 2009). Fiscal councils and

\footnotetext{
${ }^{9}$ See country experiences with medium-term expenditure frameworks at http://blog-pfm.imf.org/pfmblog/mediumterm framework/.
} 
peer-monitoring processes can enhance accountability in implementing fiscal rules or adjustment plans.

14. BLNS are strengthening their institutions and the two remaining issues are the design of the adjustment itself and further improvements in transparency. An area of particular focus is the implementation of medium-term frameworks (Botswana, Swaziland) to anchor budgets to medium-term fiscal objectives or to the development of program budgeting (Namibia). Additional steps have also been taken to strengthen spending controls (Lesotho, Namibia, and Swaziland). These efforts complement those in tax administration. Although institutional changes are moving forward, the main hurdle appears to be in the design of the adjustment plan and its effective implementation. On the former, the rest of this paper provides guidelines, emphasizing the need to evaluate the impact on growth of alternative adjustment policies (Sections III and IV). However, to complement this, transparency should be another area of greater focus. The magnitude of the adjustment would indeed require strong support from all stakeholders. Therefore, it would be advisable for the BLNS authorities to ensure that beyond the specificities of their adjustment plans, they also commit to the highest standards in terms of fiscal reporting and transparency.

\section{A Dynamic Model with Demand and Supply EfFects}

15. This section briefly describes the model used for simulating the effects of various fiscal consolidation strategies in response to the projected decline in SACU transfers. ${ }^{10}$ The model extends those constructed in Berg and others (2010), Berg and others (2011), and Mongardini and others (2011). Its dynamic, general-equilibrium structure provides a coherent framework to trace the macroeconomic effects of fiscal consolidations from the original steady state (i.e., the state before a permanent SACU transfer reduction) to a new steady state (i.e., the state reached years after such a reduction). Appendixes I and II contain model specification and calibration.

16. Policy choices are predicated on the assumption that the government does not engage in additional borrowing as a way to make up for the financing gap. Thus, the only option is to adjust the fiscal stance, either by increasing revenue, decreasing spending, or both. The debt pattern remains otherwise fixed.

\section{A. Overview of the Model}

17. The model economy is populated by two types of households: savers and handto-mouth consumers. Savers are forward-looking, with access to financial and capital markets so they can smooth consumption across periods. In contrast, hand-to-mouth households consume all disposable income each period. A relatively large share of hand-tomouth households is an important feature for low-income countries because of a less-

\footnotetext{
${ }^{10}$ Appendix I includes a detailed technical description of the model specification.
} 
developed financial sector. Savers, on the other hand, allocate their disposable income to various forms of assets (they include real money balances, domestic government bonds, and foreign assets), which are subject to portfolio investment costs, as a way to capture imperfect capital mobility. All households consume a composite good made of a traded good and a non-traded good.

\section{The production of traded and non-traded goods uses labor (supplied by} households), private capital, and public capital. Firms in the non-traded sector are monopolistically competitive and face price adjustment costs, so prices are sticky. Firms in the traded sector, on the other hand, face perfect competition and flexible prices. In both sectors, firms accumulate capital through investments, which are subject to adjustment costs. The presence of price and capital adjustment costs is important to capturing the macroeconomic short-run effects of the SACU transfer reductions.

\section{In addition to the traded and non-traded good sectors, the economy includes a} natural resource sector. Mining is a major economic activity in Botswana and Namibia, and resource revenue is an important part of government revenue. ${ }^{11}$ Including a natural resource sector makes it possible to analyze fiscal consolidation strategies that involve the immediate use of revenue associated with this sector or a gradual use of this revenue through decumulating a sovereign wealth fund. For simplicity, the resource sector is assumed to use only capital for production and all of its output is exported.

\section{Tax policy in the model includes consumption taxes (a form of value-added} taxes), labor income taxes, and resource taxes. It also allows the government to save resource revenue in a sovereign wealth fund. Government spending policy consists of transfers to households and purchases of goods and services for government consumption and investment. Government consumption is assumed to be nonproductive, ${ }^{12}$ and government investment can be transformed to productive public capital, raising the marginal productivity of private production inputs. Like private consumption, government purchases also consist of traded and non-traded goods. The composition depends on the degree of home bias of government purchases of each country.

\section{While the model allows for various types of monetary policies, for BLNS, this} paper focuses on a fixed exchange rate regime. In the model, monetary policy can be implemented through a money growth rule that targets CPI inflation; and the international reserve policy rule can accommodate different types of exchange rate regimes. Because

\footnotetext{
${ }^{11}$ For Swaziland the size of the natural resource sector is calibrated at almost zero.

12 This assumption could be relaxed, e.g., by including consumption in the utility function. However, the purpose of this paper is to focus on the fiscal adjustment and its growth implications, rather than welfare issues.
} 
BLNS currencies are pegged to the rand, in this paper we concentrate on the analysis of fixed exchange rate regimes.

\section{B. Fiscal Consolidation Strategies}

22. In response to a permanent reduction in SACU transfers, some measures of fiscal consolidation are necessary to ensure that a government is on a sustainable budget path. Given the large decline in transfers (about 15 percent of GDP in the case of Swaziland), a fiscal consolidation strategy that involves one fiscal instrument, such as exclusively increasing the consumption tax rate or solely cutting government consumption, may not be sufficient to close the budget gap. For example, as discussed below, it may not be politically feasible to raise tax rates beyond a particular level, or tax evasion could become so severe that it makes it impossible to collect sufficient revenue. However, to understand the different mechanisms under which fiscal consolidations affect the real economy, it may be useful to look at the adjustment under single instruments. Thus, in the remainder of the paper we explore both single- and multiple-instrument strategies.

\section{Single-instrument strategies}

23. For adjustment strategies involving single instruments, the paper considers four instruments: cutting government consumption or investment and increasing the consumption or labor tax rate. To determine the adjustment magnitudes of an instrument, the adjusting instrument would vary to satisfy the government budget constraint each period, while all other fiscal variables are held at their original steady states. For example, when government consumption adjusts alone in response to a SACU transfer reduction, government investment, transfers, and all tax rates do not change while government consumption falls to balance the budget. ${ }^{13}$

\section{Multiple-instrument strategies}

\section{The following multiple-instrument strategies are also considered:}

- Increasing the consumption tax rate and cutting government consumption. The consumption tax rate rises in response to a reduction of SACU transfers and is complemented by cutting government consumption, provided that all other fiscal variables (government investment, transfers to households, all tax rates except the

\footnotetext{
${ }^{13}$ Some of the single-instrument policies may not always work, as an expenditure cut can only be used to the extent that the level before the cut is greater than the fall in SACU transfers.
} 
consumption tax rate, and total government debt) do not change from the original steady state. ${ }^{14}$

- Increasing the labor tax rate and cutting government consumption. Similar to the previous option, the labor tax rate responds to a reduction of SACU transfers. For a given labor tax rate and other fiscal variables (at their original steady states), government consumption adjusts to satisfy the government budget constraint. ${ }^{15}$

- Increasing both the labor and consumption tax rates. Under this option, the labor tax rate follows a similar rule to the one of the previous case. The consumption tax rate adjusts to satisfy the government budget constraint, and all fiscal variables are set to their steady states each period except the consumption and labor tax rates.

- $\quad$ Drawing down on the sovereign wealth fund and increasing the consumption tax rate. The sovereign wealth fund is assumed to earn a constant rate of return, and its interest income is treated as part of government revenue each period. ${ }^{16}$ The consumption tax rate adjusts to satisfy the government budget constraint each period, provided the sovereign wealth fund and other fiscal variables are held at their steady states. ${ }^{17}$

${ }^{14}$ Specifically, let $\tau_{t}^{c}$ be the consumption tax rate, $s_{t}$ be the relative price of a unit of foreign goods to domestic consumption goods, and $A_{t}^{*}$ be the SACU transfers. Then, $\log \left(\frac{\tau_{t}^{c}}{\tau^{c}}\right)=\rho_{\tau} \log \left(\frac{\tau_{t-1}^{c}}{\tau^{c}}\right)+\phi^{t c} \log \left(\frac{s_{t} A_{t}^{*}}{s A^{*}}\right)$, with $\phi^{t c} \leq 0$, where $\rho_{\tau}$ indicates the persistence of the consumption tax process, and a variable without a time subscript indicates its original steady state. The equation implies that a 1 percent reduction of SACU transfers from its steady state triggers a $\phi^{\text {tc }}$-percent increase in the consumption tax rate from its original steady state. Given the new consumption tax rate in the equation above and all other fiscal variables remaining unchanged, government consumption adjusts to satisfy the government budget constraint each period (see (A.24) in Appendix I).

${ }^{15}$ Let $\tau_{t}^{l}$ be the labor tax rate. It follows the following process:

$\log \left(\frac{\tau_{t}^{l}}{\tau^{l}}\right)=\rho_{\tau} \log \left(\frac{\tau_{t-1}^{l}}{\tau^{l}}\right)+\phi^{t l} \log \left(\frac{s_{t} A_{t}^{*}}{s A^{*}}\right)$, with $\phi^{t l} \leq 0$.

${ }^{16}$ See (A.22) and (A.25) in Appendix I for resource revenue and total government revenue.

${ }^{17}$ Let $F_{t}^{*}$ be the sovereign wealth fund that holds international financial assets, $\pi^{*}$ be the foreign CPI inflation rate, and $n$ be the long-run deterministic growth rate of the economy. When the sovereign wealth fund responds to the reductions in SACU transfers, it evolves according to the process,

$\log \left(\frac{F_{t}^{*}}{F^{*}}\right)=\frac{1}{n \pi^{*}} \log \left(\frac{F_{t-1}^{*}}{F^{*}}\right)+\phi^{f} \log \left(\frac{s_{t} A_{t}^{*}}{s A^{*}}\right)$, with $\phi^{f} \leq 0$. 


\section{ECONOMiCS OF Single-InSTRUMENT Fiscal Consolidations to SACU Transfer REDUCTIONS}

\section{The SACU transfer reduction will imply both a fiscal and an external}

adjustment. Indeed, governments will have to adjust-increase taxes or reduce expenditures - to balance their budget constraints in the face of lower resources. But they will also have to tackle the balance-of-payments problem associated with an external transfer reduction, which could become even more challenging in a fixed exchange regime. As a result, the issue of how to think about real exchange rate adjustment and the challenges that poses is of first-order.

\section{When government consumption is the only fiscal instrument that adjusts to the} fall in SACU revenue, inflation falls in the short run. Consider for instance the case of Namibia, whose simulations of some selected macroeconomic variables are presented in Figure 2. ${ }^{18}$ The short-run macroeconomic effect of the SACU transfer reduction is mainly driven by its impact on government consumption, in particular on non-traded goods, because they represent a large share of public expenditures. Because of nominal price rigidities, the supply of non-traded goods contracts in response to lower demand. This contraction causes a decline in labor demand, which contributes, in turn, to a decline in real wages. With lower real wages, and hence lower real marginal costs, non-traded goods inflation falls. But because the exchange rate is fixed, this translates into a lower CPI inflation. Note that this is consistent with the loss of international reserves, which, absent any sterilization policy, implies a large decrease in money supply. ${ }^{19}$

\section{The reduction in government consumption also causes real exchange rate} depreciation. The real exchange depreciates as non-traded good prices go down and traded good prices remain constant. The real depreciation makes traded goods relatively more expensive, lowering imports and inducing an increase in traded output. Here, the increase in traded output is accomplished by drawing capital and labor from the non-traded sector. Higher traded output and lower consumption of traded goods, on the other hand, imply that the fiscal consolidation translates into an improved trade deficit.

28. In addition, real GDP is negatively affected. In the short run, the contraction in the non-traded sector, which is demand-determined, generates a short-lived decline in real GDP. Over time, as nominal rigidities dissipate, the demand-driven slowdown fades and, in fact,

\footnotetext{
${ }^{18}$ Annual impulse responses of these variables are measured as percentage deviations from the steady state, unless otherwise noted.

${ }^{19}$ Note that the nominal interest rate decreases. Using the money demand equations from the savers and handto-mouth consumers and the monetary rule, it is possible to show that the nominal interest rate is an increasing function of consumption and inflation. As both inflation and consumption declines, the nominal interest rate goes down.
} 
GDP bounces back. However, as public investment is kept constant whereas private investment declines, a persistent and negative effect on GDP exists over the medium term. The overall GDP effect depends on the combination of the production decline in the nontraded sector and the increase in the traded sector. For instance, the higher the degree of price nominal rigidities in the non-traded sector the more negative the overall impact on GDP, especially in the short run; on the other hand, when there are higher learning-by-doing externalities in the traded sector the less negative (or even positive) the real GDP response, in particular, in the medium term. ${ }^{20}$

\section{When government investment is the sole instrument that adjusts, the impact on} real GDP is more negative relative to the case when only consumption adjusts. Consider again the case of Namibia, whose simulations of some selected macroeconomic variables under both policies of cutting public consumption and investment are presented in the first row of Figure 3. On the demand side, cutting government investment has similar effects to cutting government consumption, assuming the degree of home bias is the same for these two types of public expenditures. However, because cutting public investment affects public capital negatively, then reducing investment has the additional supply-side effect of lowering the marginal productivity of capital and labor in private production. Consequently, there is a more negative and longer-lasting effect on real GDP than the one present when government consumption adjusts. The output effect of cutting government investment depends crucially on the output elasticity with respect to public capital.

\section{In comparison with the case of reducing public consumption, raising the} consumption tax rate induces a smaller real depreciation but not necessarily a more negative effect on real GDP. Raising the consumption tax rate has a direct negative impact on private consumption. However, because private agents often have a lower degree of home bias than that of the government, the demand for non-traded goods does not fall as much as when public consumption is cut. As a result, the CPI inflation decline and the real exchange rate depreciation are not as pronounced as those resulting from reducing government consumption (see the second row of Figure 3). With lower real depreciation, the increase in traded-goods production also is smaller. Nevertheless, the overall GDP effect depends on the reduction in non-traded production relative to the increase in traded-goods production. Under the calibration for Namibia, raising consumption taxes induces a smaller negative effect on non-traded production, compared to cutting public consumption.

\section{Raising the labor tax rate has a more negative impact on real GDP than} reducing public consumption. Raising the labor tax rate discourages labor supply and reduces households' disposable income, which translates into a fall in private consumption of both traded and non-traded goods (see the third row of Figure 3). CPI inflation falls, and the real exchange rate depreciates but not as much as it does with government spending, because

\footnotetext{
${ }^{20}$ For the definition of the learning-by-doing externality in the traded sector, see A.2.2 in Appendix I.
} 
again private agents have a lower degree of home bias than the government. The real depreciation encourages more production of traded goods. However, the decline in labor lowers the marginal product of capital, which further discourages private investment in each sector. The reduction of both labor and private capital negatively affects the production of non-traded goods - which is falling-but more importantly it slows the recovery of the traded sector-which is increasing given the real depreciation. The overall effect is a more persistent and negative effect on real GDP than that when public consumption adjusts. The negative effect of raising the labor income tax rate on GDP depends crucially on the Frisch elasticity of labor supply. ${ }^{21}$ When the elasticity is small, raising labor tax rates has a less negative effect on GDP.

\section{A cross-country comparison of the single-instrument adjustments reveals that}

they may not be politically feasible. For example, an adjustment of labor taxes in Swaziland would require more than tripling the effective tax rate, from about 20 percent to 70 percent; while the labor tax would have to be raised in Namibia by more than 10 percentage points (see Figure 4). In Lesotho and Swaziland, the implied cut in government investment is not feasible because it would be much bigger than historical levels of public investment. These simulations therefore indicate that single-instrument policies may not be sufficient to correct the budget imbalances associated with the reduction in SACU transfers.

\section{A cross-country comparison also shows that cutting government investment and} raising labor tax rates have a more negative effect on real GDP than other instruments. Figure 4 shows that, across SACU countries, the negative effects on real GDP are more pronounced when cutting government investment or raising labor taxes than when cutting government consumption or raising consumption taxes. The reason is that reducing public investment or increasing labor taxes have a direct impact on the supply side of the economy. Reducing government investment negatively affects both the marginal product of labor and the marginal product of capital (MPK). A lower MPK, in turn, discourages private investment, which has a long-lasting negative effect on GDP. Raising labor tax rates, on the other hand, mainly lowers the labor supply and hence employment. This has a direct negative effect on real GDP and an indirect effect through lowering MPK and discouraging private investment.

\footnotetext{
${ }^{21}$ The Frisch elasticity measures the substitution effect of a change in the wage rate on labor supply: it captures the elasticity of hours worked to the wage rate, given a constant marginal utility of consumption.
} 
Figure 2. Impact of Government Consumption Adjustment for Namibia, in Response to a Decline in SACU Transfers

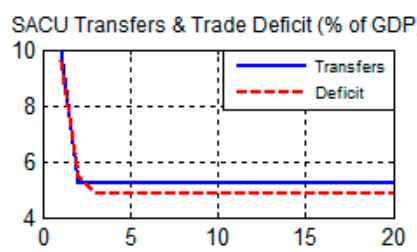

CPI inflation (\%)

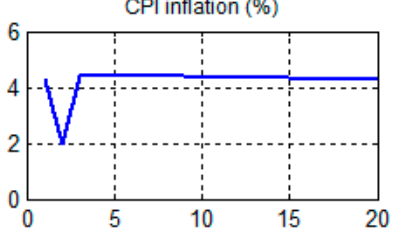

Interest Rates (\%)

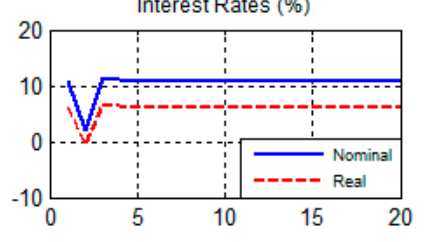

Tax Rates (\%)

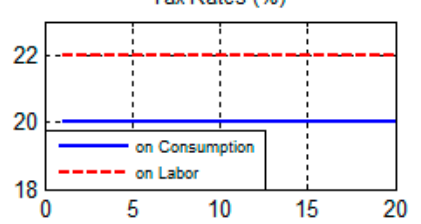

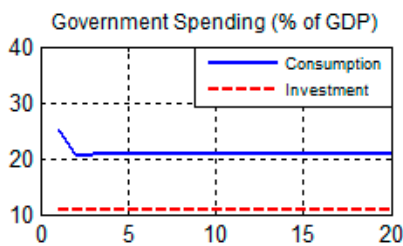

Sectoral Inflation (\%)

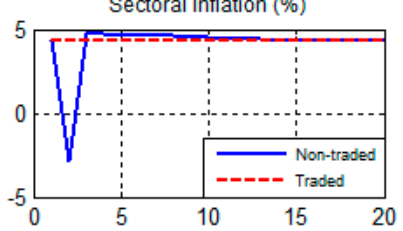

Private Absorption

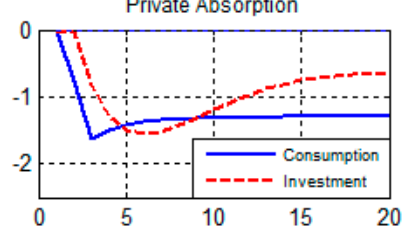

Sectoral Output

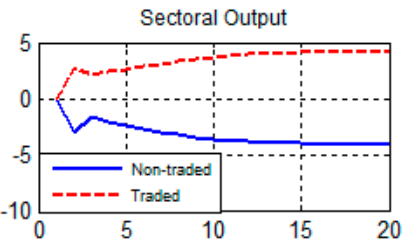

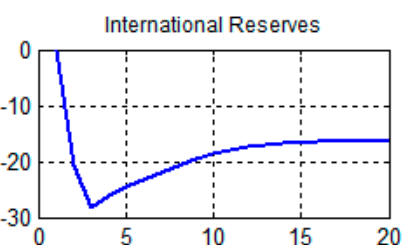
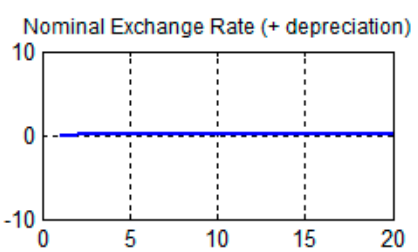

Capital

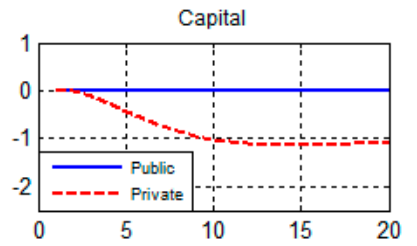

Non-traded Sector

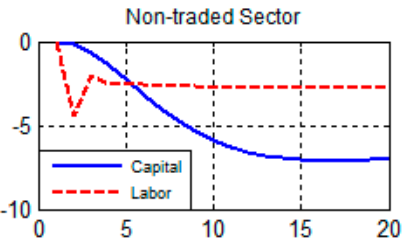

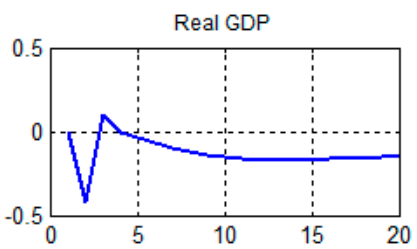

Real Exchange Rate

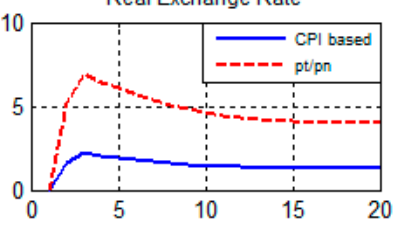

Labor Market

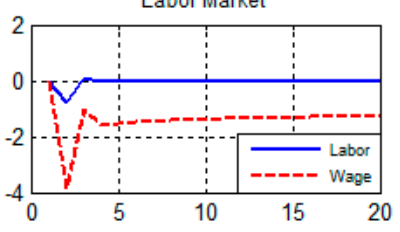

Traded Sector

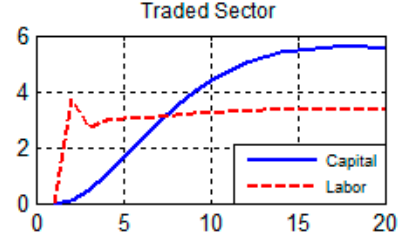

Note: Annual responses are measured as percentage deviations from the steady state, unless otherwise noted. The charts are done using the example of Namibia. For other countries the model provides similar reasoning, although results can differ significantly (see Section V). 
Figure 3. Comparison of the Different Single-Instrument Adjustment Strategies for Namibia
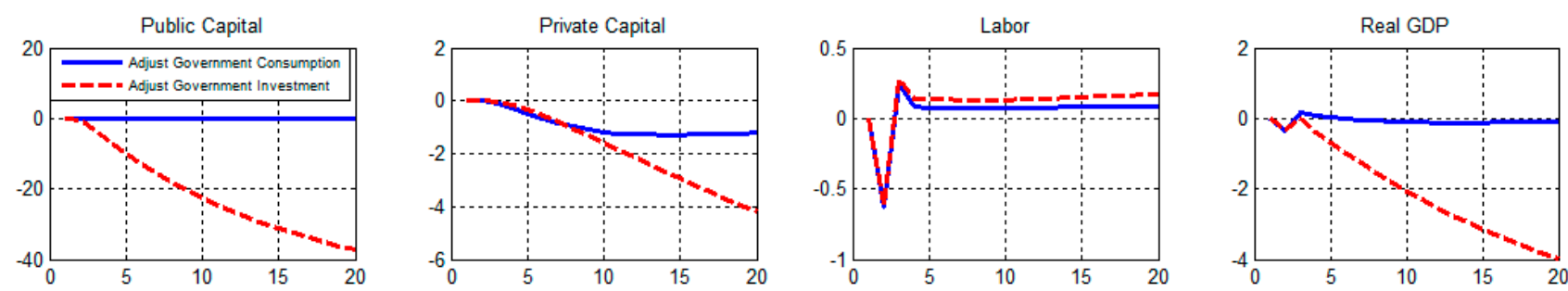

Private Consumption
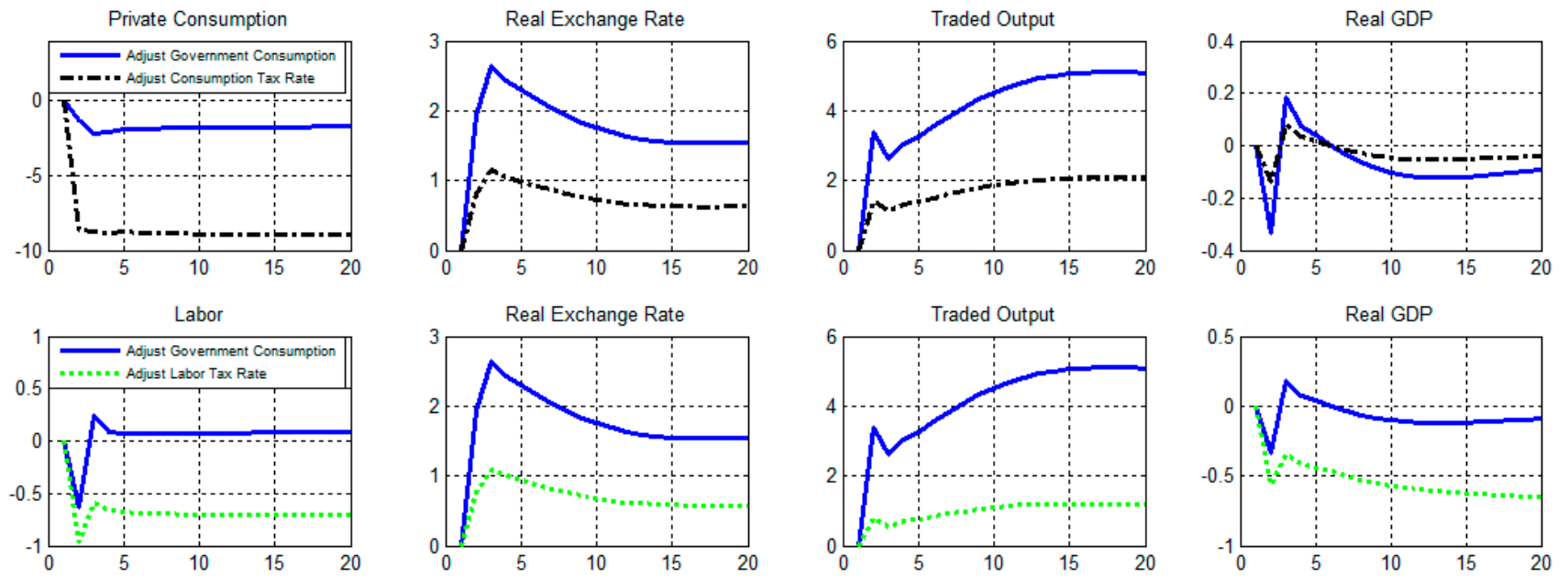

Note: (i) adjusting government consumption versus adjusting government investment (first row), (ii) adjusting government consumption versus adjusting the tax rate on consumption (second row), and (iii) adjusting government consumption versus adjusting the tax rate on labor (third row). Annual responses are measured as percentage deviations from the steady state, unless otherwise noted. The charts are done using the example of Namibia. For other countries the model provides similar reasoning, although results can differ significantly (see Section V). 
Figure 4. Cross-Country Comparison of Different Single-Instrument Fiscal Consolidations and Their Effects on Real GDP

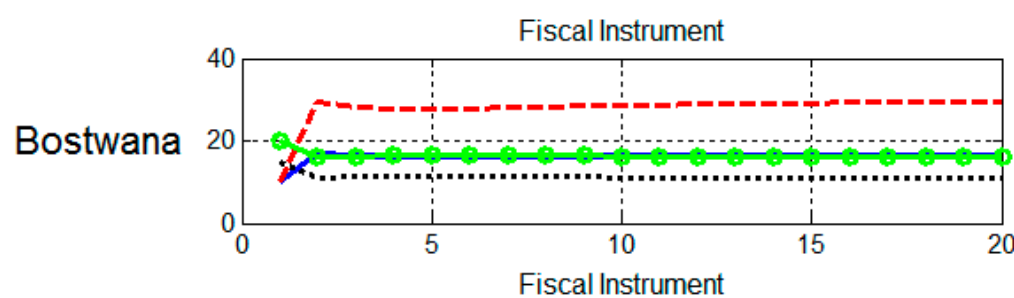

Fiscal Instrument

Lesotho

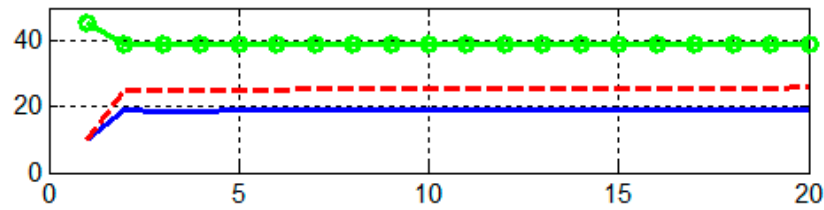

Fiscal Instrument

Namibia

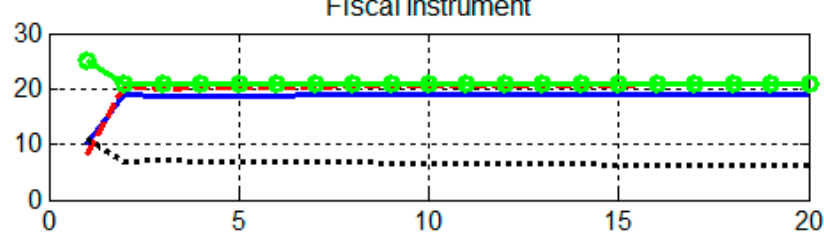

Fiscal Instrument

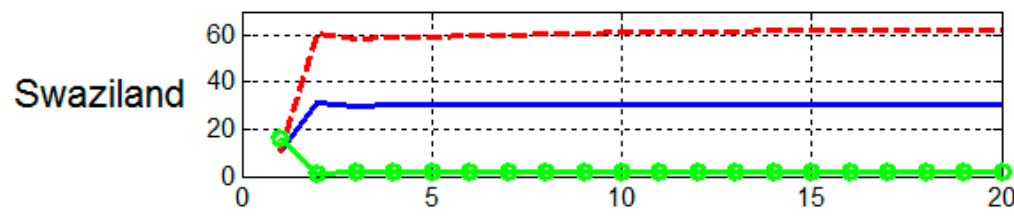

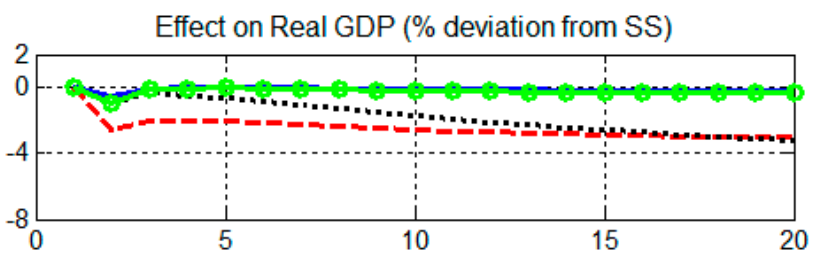

Effect on Real GDP (\% deviation from SS)

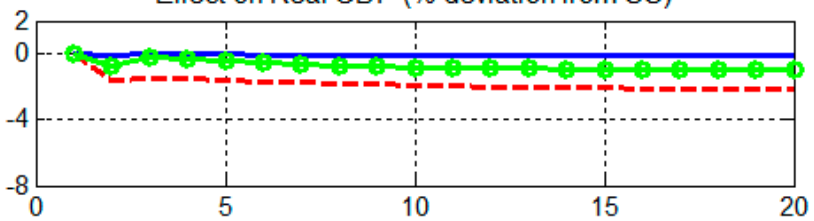

Effect on Real GDP (\% deviation from SS)

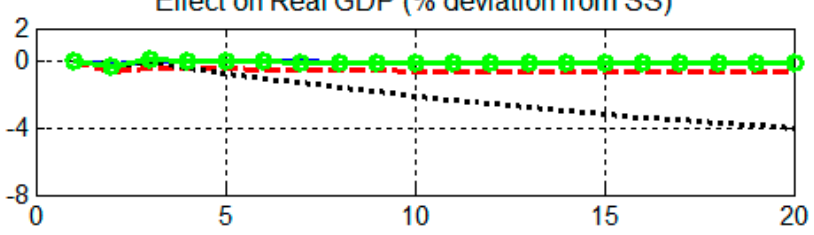

Effect on Real GDP (\% deviation from SS)

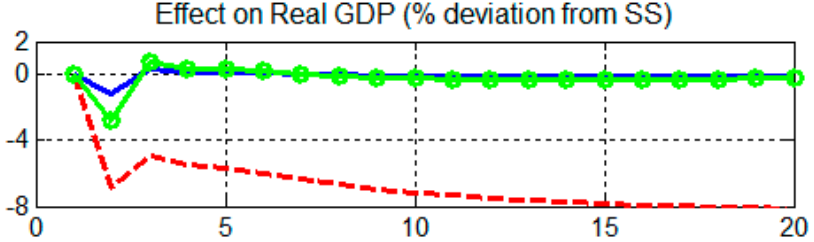

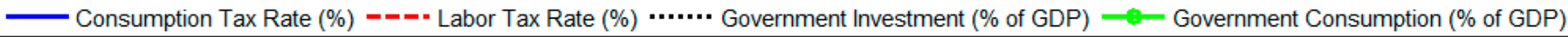

Note: Annual responses are measured as percentage deviations from the steady state. Government investment cuts alone are not feasible for Lesotho and Swaziland, because the level of public investment is lower than the loss of SACU transfer. 


\section{Analyzing Fiscal Policy Options}

\section{A comprehensive fiscal consolidation strategy would need to be based on}

multiple instruments. As discussed in the previous section, single-instrument strategies are simply not feasible given the magnitude of the adjustment. Adjustment strategies should therefore rely on a combination of instruments. Additionally, such strategies may also be critical to securing broad political consensus on the reform, especially if otherwise only a specific section of the population (e.g., workers in a labor tax increase) were to carry the burden of the adjustment.

\section{The simulations underscore that adjustments based on strong consumption measures, such as a government consumption cut or a consumption tax increase, ${ }^{22}$ are dominant strategies from the perspective of their impact on growth (Figure 5, Table 2).}

All countries have a dominant strategy in their fiscal consolidation by combining government consumption cuts and consumption tax increases, except for Lesotho, which appears to have another option with consumption and labor taxes. This result is a corollary of the singleinstrument strategies discussed in the previous section, where both of these instruments mitigate best the negative impact on growth. Fundamentally, cutting consumption, by lowering demand, puts downward pressure on wages, thus improving price competitiveness and growth prospects for the traded-good sector. Lesotho is a specific case, where the best strategy would first appear to combine a labor tax increase together with a consumption tax increase. This result comes from the large absorption of the non-traded sector output by the public sector, combined with a relatively smaller size of its traded-good sector. However, this policy would have to primarily rely on revenue collection improvements and reducing tax exemptions, instead of increasing policy rates (the VAT rate is around 15 percent for goods and services, which is relatively high compared to the region). Additionally the results come also largely from the very large size of the government (government spending represented about 2/3 of GDP in 2009/10). From this perspective, although simulations on government cuts highlight how it could lead to a significant contraction of the non-traded sector, the large size of the government would still point out the need to follow the route of spending cuts It would also help further strengthen a relative weak external position (international reserves cover about $3 \frac{1}{2}$ months of imports).

\footnotetext{
${ }^{22}$ Tax adjustments may need to be coordinated within SACU.
} 
Table 2. Long-Term Real GDP Growth Response

\begin{tabular}{|c|c|c|c|}
\hline & Total & Traded & Nontraded \\
\hline \multicolumn{4}{|l|}{ Botswana } \\
\hline Government consumption and consumption tax & -0.2 & 4.2 & -1.9 \\
\hline Consumption tax and labor tax & -0.9 & 3.0 & -2.6 \\
\hline SWF ${ }^{2}$ and consumption tax & -0.1 & 4.3 & -1.9 \\
\hline \multicolumn{4}{|l|}{ Lesotho } \\
\hline Government consumption and consumption tax & -0.7 & 3.9 & -6.1 \\
\hline Consumption tax and labor tax & -0.3 & 0.7 & -1.7 \\
\hline \multicolumn{4}{|l|}{ Namibia } \\
\hline Government consumption and consumption tax & -0.1 & 3.5 & -3.3 \\
\hline Consumption tax and labor tax & -0.2 & 1.9 & -2.1 \\
\hline \multicolumn{4}{|l|}{ Swaziland } \\
\hline Government consumption and consumption tax & -0.2 & 20.8 & -13.0 \\
\hline Consumption tax and labor tax & -0.9 & 10.6 & -8.0 \\
\hline
\end{tabular}

\section{In contrast, the negative impact on productivity of lower public investment} makes policies based on this instrument clearly dominated. Figure 5 shows that the GDP responses with public investment cuts range from 2 points lower than the steady state (Lesotho, Namibia) to 4-5 points lower (Botswana, Swaziland). Lower public investment spreads out to the rest of the economy by lowering the productivity of private investment. Even with a companion instrument, the strong negative impact of investment remains dominant. The simulation therefore has strong policy implications: to alter the negative impact of fiscal consolidations, investment spending must be protected. However, the recommendation would only apply to "true" investment spending, that is, spending that effectively contributes to enhancing the productivity of the private sector. Assessing investment projects both from their costs and benefits perspectives is therefore essential, because, for example, cutting prestige investment spending would, in reality, be similar to a cut in government consumption, rather than a true investment cut.

\section{Moving away from labor tax increases stimulates even more growth in the}

traded-good sector. This result is clearly highlighted by the growth-impact decomposition of the dominant strategies, even in the case of Lesotho. The contrasted responses in the traded good and non-traded good sectors highlight the potential benefits of engaging fiscal consolidation with a careful choice of instruments. Not only can these strategies achieve the stabilization objective, but they can also adequately address structural competitiveness issues. Beyond the simple message provided by the simulations, the results have to be analyzed in comparison to the weight of the wage bill in these countries (Figure 1) and, to some extent, the generous public wage policies. Although not formally included in the model, taking into account public wages would only reinforce the message on the development of the tradedgood sector. With prudent wage policies, including the implementation of nominal wage cuts when appropriate, and overall restraints on public consumption, governments in BLNS can promote even stronger growth of the traded-good sector when implementing their fiscal 
consolidation. Potentially, such policies would eventually create a virtuous growth circle, whereby private sector long-term growth would be even stronger.

38. Sovereign wealth funds (SWF) could also be used to ease the adjustment, but it has to be combined with other instruments. The effects from such a policy mainly come from the accompanying instrument (in our case a consumption tax), which adjusts to make up for SACU transfer reduction. Despite this caveat, the use of an SWF can indeed provide some relief in the adjustment effort. It has, however, two major hurdles: (i) the depletion of the SWF raises government net debt, potentially creating debt vulnerability even with an unchanged gross debt and (ii) it is better suited for a temporary shock, whereas the drawdown of the SWF cannot be sustained in a permanent shock. Overall, the use of the SWF has not had a significantly different impact on growth than using the consumption tax alone-even in the case of Botswana, where the existing fund, although not designed to be used to compensate for lower revenue, is large.

39. External imbalances are significantly reduced by the fiscal consolidation, mirroring the contraction of domestic absorption (Figure 6). By reducing government imbalances, the fiscal consolidation has a strong negative impact on domestic absorption. Overall the immediate deterioration of the current account balance, following the sharp drop in SACU transfers (Table 1), is fairly limited. This reflects the strong fiscal response, the contraction in domestic demand, and competitiveness improvements. For most countries, with the notable exception of Lesotho, all fiscal consolidation designs perform equally well over the medium term. After a short-lived deterioration of the current account balance, it takes about 1 to 2 years, on average, to reach a level similar to the one before the fall in SACU transfers. Not surprisingly, the adjustment is much slower when the SWF is used in Botswana, because the adjustment of demand takes place more gradually. Lesotho brings a different perspective to the fiscal consolidation. The best strategy in terms of the growth impact, namely, taxing consumption and labor income, is actually less efficient in improving the current account balance (by about $1 / 4$ percent of GDP). This is, again, due to the relatively lower weight of the external sector for this country and the relatively higher weight of the government sector.

\section{Fiscal multipliers for the different options are in line with the empirical} evidence, but they are affected by these policy options. The output multipliers are computed as the ratio of the present value of the cumulative nominal GDP changes over the one-year horizon to the present value of the cumulative nominal SACU transfer changes over the same horizon. The discount factors used are constructed from model-implied interest rate paths. The multipliers calculated in Table 3 show that strategies relying more on government investment or rising labor taxes have bigger multipliers - implying more contractionary output effects - than those relying more on government consumption cuts or increased 
consumption taxes. ${ }^{23}$ Across countries, some noticeable differences are observed: Lesotho would be more negatively affected by a contraction of government spending than other countries, reflecting the large share of the non-traded good sector in this country. Although the model setup and calibrations do not account for all economic uncertainties, it is still reassuring that the calculated multipliers are to a great extent consistent with the aforementioned empirical literature (see Section II.A).

Table 3. Multiplier Across Different Fiscal Consolidation Strategies

\begin{tabular}{|c|c|c|c|c|}
\hline & Botswana & Lesotho & Namibia & Swaziland \\
\hline \multicolumn{5}{|l|}{ Short-term multiplier (1 year) } \\
\hline Government consumption and investment & 0.32 & 0.43 & 0.26 & 0.36 \\
\hline Government consumption and labor tax & 0.35 & 0.43 & 0.25 & 0.36 \\
\hline Government consumption and consumption tax & 0.30 & 0.41 & 0.24 & 0.34 \\
\hline Consumption tax and labor tax & 0.22 & 0.10 & 0.11 & 0.17 \\
\hline SWF $^{1}$ and consumption tax & 0.15 & $\ldots$ & $\ldots$ & $\ldots$ \\
\hline \multicolumn{5}{|l|}{ Long-term multiplier (20 years) } \\
\hline Government consumption and investment & 0.38 & 0.47 & 0.34 & 0.28 \\
\hline Government consumption and labor tax & 0.33 & 0.40 & 0.20 & 0.24 \\
\hline Government consumption and consumption tax & 0.16 & 0.34 & 0.16 & 0.18 \\
\hline Consumption tax and labor tax & 0.23 & 0.11 & 0.11 & 0.13 \\
\hline SWF $^{1}$ and consumption tax & 0.12 & $\ldots$ & $\ldots$ & \\
\hline
\end{tabular}

${ }^{1}$ Sovereign wealth fund.

\footnotetext{
${ }^{23}$ Normally, fiscal multipliers are used to characterize the expansionary effect of a fiscal policy change, and a larger multiplier implies a more expansionary effect. Here, the multiplier is a negative output change induced by fiscal adjustments (reductions in government spending or raising taxes) associated with a negative SACU transfer change. Thus, a bigger multiplier number implies a larger contractionary effect on output.
} 
Figure 5. GDP Response to Different Policy Instruments ${ }^{1}$
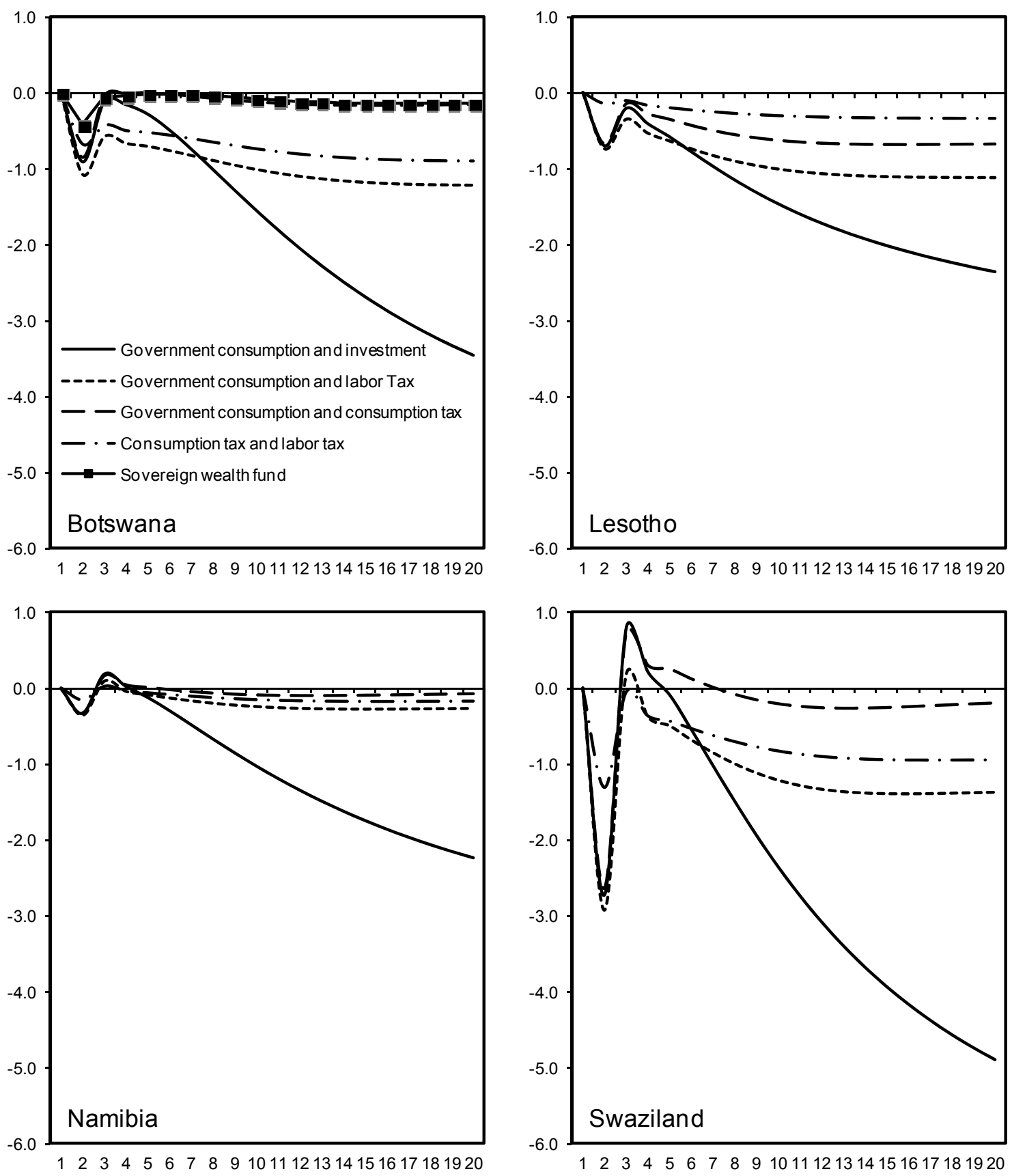

${ }^{1}$ Points of GDP deviation from steady-state. 
Figure 6. Current Account Balance Response to Different Policy Instruments ${ }^{1}$
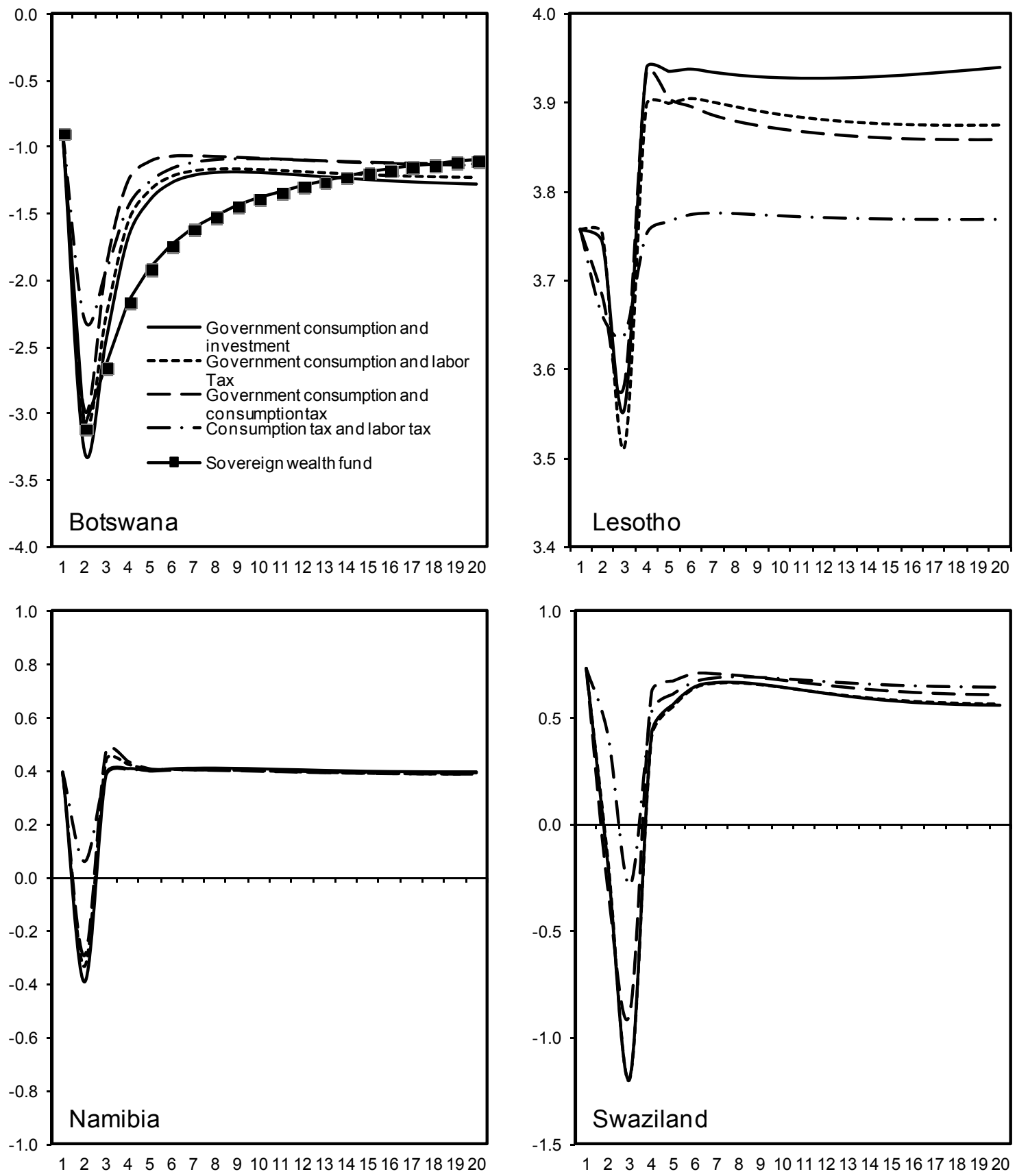

${ }^{1}$ Points of GDP deviation from the steady-state. The current account balance is proxied by the sum of trade balance and SACU transfers, the other items of the balance of payments, except the reserves of the central bank, held constant vis-à-vis the steady-state. 


\section{Conclusion}

41. Overall, the design of fiscal adjustments needs to rely on multiple instruments, with a strong emphasis on reducing consumption, particularly in the public sector. Under the assumption of a strong and permanent fall in SACU transfers, BLNS would have to pursue fiscal consolidation. The simulations in this paper indicate that focusing on reducing consumption (government consumption, consumption tax) is most effective in bringing about the adjustment and mitigating the impact on growth. Reducing consumption not only restores fiscal sustainability, but also puts downward pressure on prices, contributing to reducing external imbalances. Moreover, by improving price competitiveness, government consumption cuts may provide better prospects for medium-term growth. The results from the simulations also show a significant cost for cutting government investment, arguing for preserving this type of public spending as long as it effectively contributes to productivity improvements. Cost-benefit assessment of investment projects could provide helpful guidance in assessing whether they are conducive to these improvements. If not, investment should be considered as unproductive consumption.

\section{Fiscal adjustments for BLNS need to be complemented by key public finance} management reforms to ensure their sustainability. Among such measures, the following are of critical importance: identifying contingencies, strengthening medium-term frameworks, and improving taxpayer compliance. All these measures require not only a welldesigned fiscal consolidation plan but also continued efforts in fiscal transparency to ensure large ownership of the adjustment plans. From this perspective, public communication strategies on the specific targets to achieve, both in the short and medium term, can help in the adjustment, particularly if the instruments to achieve these targets are also specified. Committing to well-designed fiscal adjustments while preserving the most needed spending (education, health, and infrastructure) can indeed help secure broad support for reforms, not only from the population but also from donors.

\section{Although the fiscal adjustment can be delayed by additional borrowing, it may}

not be feasible. All the adjustment scenarios in our simulations are predicated on excluding borrowing strategies. The SACU shortfall is therefore completely offset by policy adjustments. Such an abrupt adjustment can, in practice, have a detrimental impact on growth, thus calling for a more spread-out adjustment. External borrowing can provide the additional cushion on the balance of payments side. Domestic borrowing also can be considered to alleviate the adjustment. However, delaying the adjustment may not always be feasible. It depends on the availability of financing and other structural characteristics of the economy. For instance, under a fairly closed capital account, borrowing domestically can induce a bigger real depreciation, a bigger fall in nominal wages, and private demand crowding out. Moreover, although additional domestic and/or external financing provides short-term relief, it may also induce higher interest rates (which can be compounded into debt) and increase the vulnerability of these economies to external shocks. In this case, delaying the fiscal consolidation may ease short-term pressure at the expense of increasing 
the size of the required adjustment in the medium term. Hence a front-loaded adjustment may be more appropriate. 


\section{REFERENCES}

Ardagna, S., 2004, "Fiscal Stabilizations: When Do They Work and Why?" European Economic Review 48, pp. 1047-74.

Berg, A., J. Gottschalk, R. Portillo, and L.-F. Zanna, 2010, “The Macroeconomics of Medium-Term Aid Scaling-up Scenarios,” IMF Working Paper WP/10/160 (Washington: International Monetary Fund). Available via the Internet: http://www.imf.org/external/pubs/ft/wp/2010/wp10160.pdf

Berg, A., R. Portillo, S.-C. S. Yang, and L.-F. Zanna, 2011, Government Investment in Resource Abundant Low-Income Countries, manuscript (Washington: International Monetary Fund).

Guajardo J., D. Leigh, and A. Pescaroti, 2011, "Expansionary Austerity: New International Evidence," IMF Working Paper WP/11/158 (Washington: International Monetary Fund). Available via the Internet: http://www.imf.org/external/pubs/ft/wp/2011/wp11158.pdf

Gupta, S., E. Baldacci, B. Clements, and E. Tiongson, 2005, "What Sustains Fiscal Consolidations in Emerging Market Countries?" International Journal of Finance and Economics, Vol.10, pp. 307-21.

Hurlin, C., F. Arestoff, 2010, “Are Public Investments Efficient in Creating Capital Stocks in Developing Countries? Economics Bulletin 30 (4), 3177-3187.

Ilzetzki, E., E. G. Mendoza, C. A. Vegh, 2010, "How Big (Small?) Are Fiscal Multipliers?" NBER Working Paper 16479 (Cambridge, Mass.: National Bureau of Economic Research). Available via the Internet: http://www.nber.org/papers/w16479

IMF, 2005, Fiscal Responsibility Laws (Washington: International Monetary Fund).

IMF, 2009, Fiscal Rules-Anchoring Expectations for Sustainable Public Finances (Washington: International Monetary Fund). Available via the Internet: www.imf.org/external/np/pp/eng/2009/121609.pdf

IMF, 2010a, From Stimulus to Consolidation-Revenue and Expenditure Policies in Advanced and Emerging Economies (Washington: International Monetary Fund). Available via the Internet: http://www.imf.org/external/np/pp/eng/2010/043010a.pdf

IMF, 2010b, Strategies for Fiscal Consolidation in the Post-Crisis World (Washington: International Monetary Fund). Available via the Internet: www.imf.org/external/np/pp/eng/2010/020410a.pdf 
IMF, 2010c, "Will it Hurt? Macroeconomic Effects of Fiscal Consolidation," World Economic Outlook, October, Chapter 3 (Washington: International Monetary Fund). Available via the Internet: http://www.imf.org/external/pubs/ft/weo/2010/02/index.htm

Kraay, A., 2010, How Large is the Government Spending Multiplier? Evidence from World Bank Lending, manuscript (Washington: World Bank).

Kumar, M., D. Leigh, and A. Plekhanov, 2007, "Fiscal Adjustments: Determinants and Macroeconomic Consequences," IMF Working Paper 07/178 (Washington: International Monetary Fund). Available via the Internet: http://www.imf.org/external/pubs/ft/wp/2007/wp07178.pdf.

Mauro, P., 2011, Chipping Away at the Public Debt-Sources of Failure and Keys to Success in Fiscal Adjustment (Hoboken: N.J.: John Wiley and Sons).

Mongardini, J., D. Benicio, T. Fontaine, G. Pastor, and G. Verdier, 2011, "In the Wake of the Global Economic Crisis: Adjusting to Lower Revenue of the Southern African Customs Union in Botswana, Lesotho, Namibia, and Swaziland," IMF African Department \# 1/11 (Washington: International Monetary Fund). Available via the Internet: http://www.imf.org/external/pubs/ft/dp/2011/afr1101.pdf

Perotti, R., 2005, "Estimating the Effects of Fiscal Policy in OECD Countries," CEPR Discussion Paper No. 4842 (Washington: Center for Economic and Policy Research). Available via the Internet: http://www.cepr.org/pubs/new-dps/dplist.asp?dpno=4842

Pritchett, L., 2000, "The Tyranny of Concepts: Cudie (cumulated, depreciated, investment effort) Is Not Capital,” Journal of Economic Growth 5 (4), 361-384.

Romer, C., and J. Berstein, 2009, "The Job Impact of American Recovery and Reinvestment Plan," President's Council of Economic Advisors. Available via the Internet: http://www.economy.com/markzandi/documents/The_Job_Impact_of_the_American_Recovery_and_Reinvestment_ Plan.pdf

Romer, C. and D. Romer, 2010, "The Macroeconomic Effects of Tax Changes: Estimates Based on a New Measure of Fiscal Shocks," American Economic Review, 100 (June), 763-801.

Russell, B., 2010, "Revenue Administration: Developing a Taxpayer Compliance Program," IMF Technical Note 10/17 (Washington: International Monetary Fund). Available via the Internet: http://www.imf.org/external/pubs/ft/tnm/2010/tnm1017.pdf

Schmitt-Grohe, S., M Uribe, 2003, "Closing Small Open Economy Models," Journal of International Economics 61 (1), 163-185. 
Spilimbergo, A., S. Symansky, M. Schindler, 2009, “Fiscal Multipliers," IMF Staff Position Note, SPN/09/11 (Washington: International Monetary Fund). Available via the Internet: http://www.imf.org/external/pubs/ft/spn/2009/spn0911.pdf

Tsibouris, G., M. Horton, M. Flanagan, and W. Maliszewski, 2006, "Experience with Large Fiscal Adjustments," IMF Occasional Paper 246 (Washington: International Monetary Fund). Available via the Internet: http://www.imf.org/external/pubs/cat/longres.cfm?sk=18309.0

Von Hagen, J., A. Hallett, and R. Strauch, 2001, "Budgetary Consolidation in the EMU," Economic Papers, No. 148, March. Available via the Internet: http://ec.europa.eu/economy_finance/publications/publication11056_en.pdf

Wang, J.-Y., I. Masha, K. Shirono, and L. Harris, 2007, "The Common Monetary Area in Southern Africa: Shocks, Adjustment, and Policy Challenges," IMF Working Paper 07/184 (Washington: International Monetary Fund). Available via the Internet: http://www.imf.org/external/pubs/ft/wp/2007/wp07158.pdf 


\section{APPENDiX I. OUTLINE OF THE MODEL}

The model features deterministic and exogenous growth for labor-augmenting technology, so all variables grow at the same rate $n$ in the balanced-growth path. The description below is in terms of the de-trended model, which produces a stationary equilibrium.

A.1. Households. The economy is populated by two types of households: a fraction $f$ is savers, and $1-f$ is the hand-to-mouth households. Savers have access to assets and capital markets. A relatively large share of the hand-to-mouth households is an important feature for low-income countries because many households do not participate in the financial and asset markets, limiting their ability to smooth consumption over time. A superscript $a$ denotes a variable associated with savers and $h$ with the hand-to-mouth. An asterisk sign indicates a foreign variable, taken as given.

A.1.1. Savers. A representative saver derives utility from consumption $\left(c_{t}^{a}\right)$ and real money balance $\left(m_{t}^{a}\right)$ and disutility from labor $\left(l_{t}^{a}\right)$ to maximize the expected discounted sum of utility over an infinite horizon,

$$
E_{t} \sum_{t=0}^{\infty} \beta^{t}\left[u^{a}\left(c_{t}^{a}, m_{t}^{a}\right)-\frac{\kappa^{a}}{1+\psi}\left(l_{t}^{a}\right)^{1+\psi}\right],
$$

subject to the budget constraint

$$
\begin{aligned}
& \left(1+\tau_{t}^{c}\right) c_{t}^{a}+m_{t}^{a}+b_{t}^{a}+s_{t} b_{t}^{a *}+\frac{v}{2} s_{t}\left(b_{t}^{a *}-b^{a *}\right)^{2}= \\
& \left(1-\tau_{t}^{l}\right) w_{t} l_{t}^{a}+\frac{m_{t-1}^{a}}{n \pi_{t}}+\frac{i_{t-1} b_{t-1}^{a}}{n \pi_{t}}+s_{t} i^{*} \frac{b_{t-1}^{a *}}{n \pi^{*}}+\Omega_{t}^{T}+\Omega_{t}^{N}+s_{t} r m^{*}+z_{t} .
\end{aligned}
$$

The utility function takes the form

$$
u^{a}\left(c_{t}^{a}, m_{t}^{a}\right)=\frac{1}{1-\sigma}\left\{\left[\theta^{a}\left(c_{t}^{a}\right)^{\frac{\eta-1}{\eta}}+\left(1-\theta^{a}\right)\left(m_{t}^{a}\right)^{\frac{\eta-1}{\eta}}\right]^{\frac{\eta}{\eta-1}}\right\}^{1-\sigma} .
$$

$\beta$ is the constant discount factor, $\sigma$ and $\psi$ are the inverses of the elasticity of intertemporal substitution for consumption and of the Frisch elasticity of labor supply. $\kappa^{a}$ is the preference weight on leisure. $\tau_{t}^{c}$ and $\tau_{t}^{l}$ are the consumption and labor tax rates, $b_{t}^{a}$ and $b_{t}^{a *}$ are the government bonds and foreign assets, $w_{t}$ is the real wage rate, $\mathrm{rm}^{*}$ is remittances, and $z_{t}$ is government transfers. Savers are assumed to be the sole owners of firms in the non-traded and traded good sectors. $\Omega_{t}^{T}$ and $\Omega_{t}^{N}$ are the after-tax profits from each sector (defined later). 
The composite consumption $c_{t}^{a}$ consists of non-traded good $\left(c_{t}^{a N}\right)$ and traded good $\left(c_{t}^{a T}\right)$, combined into a constant elasticity of substitution (CES) basket

$$
c_{t}^{a}=\left[\varphi^{\frac{1}{x}}\left(c_{t}^{a N}\right)^{\frac{\chi-1}{\chi}}+(1-\varphi)^{\frac{1}{x}}\left(c_{t}^{a T}\right)^{\frac{\chi-1}{\chi}}\right]^{\frac{\chi}{x-1}},
$$

where $\chi$ denotes the intratemporal elasticity of substitution, and $\varphi$ indicates the degree of consumption home bias. The non-traded goods are produced by a continuum of monopolistically competitive firms, indexed by $i \in[0,1]$. Aggregating all non-traded consumption varieties yields

$$
c_{t}^{a N}=\left[\int_{0}^{1}\left(c_{i t}^{a N}\right)^{\frac{\theta-1}{\theta}} d i\right]^{\frac{\theta}{\theta-1}},
$$

where $\theta$ is the elasticity of substitution between different pairs of non-traded goods.

The CES consumption basket implies that the consumption price index for a unit of composite consumption is $P_{t}=\left[\varphi\left(P_{t}^{N}\right)^{1-\chi}+(1-\varphi)\left(P_{t}^{T}\right)^{1-\chi}\right]^{\frac{1}{1-\chi}}$, where $P_{t}^{N}$ and $P_{t}^{T}$ are the prices for non-traded and traded goods. The relative price of non-traded goods to the CPI is $p_{t}^{N} \equiv \frac{P_{t}^{N}}{P_{t}}$.

The model assumes that the law of one price holds for the traded good so $P_{t}^{T}=S_{t} P_{t}^{*}$, where $S_{t}$ is the nominal exchange rate in domestic currency per unit of foreign currency, and $P_{t}^{*}$ is the foreign CPI. The relative price of the traded good to the CPI is $s_{t} \equiv \frac{S_{t} P_{t}^{*}}{P_{t}}$, where $s_{t}$ is also the CPI-based real exchange rate.

In addition to consumption, savers allocate the disposable income in various forms of assets. They hold the real money balance $m_{t}^{a}$, domestic government bonds $b_{t}^{a}$, and foreign assets $b_{t}^{a^{*}}$. A unit of government bonds pays $\frac{i_{t} b_{t}^{a}}{n \pi_{t+1}}$ units of composite consumption goods at $t+1$, where $\pi_{t+1}$ is domestic CPI inflation. A unit of foreign assets pays $\frac{i^{*} b_{t}^{a *}}{n \pi^{*}}$ units of foreign goods at $t+1$, and the foreign CPI inflation $\left(\pi^{*}\right)$ and the foreign nominal interest rate $\left(i^{*}\right)$ are assumed to be constant. Following Schmitt-Grohe and Uribe (2003), acquiring foreign assets is subject to a portfolio adjustment cost, $\frac{v}{2} s_{t}\left(b_{t}^{a^{*}}-b^{a^{*}}\right)^{2}$, where $b^{a^{*}}$ (without a time subscript) denotes the original steady-state foreign assets held by savers. The parameter $v$ governs the degree of capital mobility. When $v$ is very large, the capital account for the private sector is almost closed as in most low-income countries. 
Savers supply labor to the non-traded and traded good sectors. The elasticity of substitution is $\rho>0$, which affects the labor mobility between the two sectors. The total labor supplied by savers is

$$
l_{t}^{a}=\left[\delta^{-\frac{1}{\rho}}\left(l_{t}^{a N}\right)^{\frac{1+\rho}{\rho}}+(1-\delta)^{-\frac{1}{\rho}}\left(l_{t}^{a T}\right)^{\frac{1+\rho}{\rho}}\right]^{\frac{\rho}{1+\rho}},
$$

where $\delta$ is the steady-state share of labor in the non-traded good sector. The aggregate real wage index is

$$
w_{t}=\left[\delta\left(w_{t}^{N}\right)^{1+\rho}+(1-\delta)\left(w_{t}^{T}\right)^{1+\rho}\right]^{\frac{1}{1+\rho}} .
$$

where $w_{t}^{N}$ and $w_{t}^{T}$ are the real wage rates in the non-traded and traded sectors.

A.1.2. Hand-to-Mouth. The hand-to-mouth households have the same utility functional form as savers in (A.1) and (A.3). To capture the short planning horizon in their economic decisions, the hand-to-mouth households solve an intratemporal optimization problem, subject to the budget constraint

$$
\left(1+\tau_{t}^{c}\right) c_{t}^{h}+m_{t}^{h}=\left(1-\tau_{t}^{l}\right) w_{t} l_{t}^{h}+\frac{m_{t-1}^{h}}{n \pi_{t}}+s_{t} r m^{*}+z_{t} .
$$

Total labor supplied by the hand-to-mouth $l_{t}^{h}$ is aggregated the same way as savers in (A.6). Note that government transfers to the two types of households are assumed the same, equal to $z_{t}$.

A.2. Firms. The economy consists of three production sectors: a nontraded-good sector (denoted by a superscript $N$ ), a traded-good sector excluding natural resources $(T)$, and a natural resource sector $(O)$. The inclusion of a resource sector allows us to model the effects of fiscal adjustments involving resource revenue. Because most natural resource output is exported in low-income countries, all the resource output in the model is assumed exported. Also, as resource production is often capital intensive, labor is excluded in production for simplicity.

A.2.1. Non-traded Good Sector. In the non-traded good sector, monopolistically competitive firm $i$ produces according to the technology

$$
y_{i t}^{N}=z^{N}\left(k_{i t-1}^{N}\right)^{1-\alpha^{N}}\left(l_{i t}^{N}\right)^{\alpha^{N}}\left(K_{t-1}^{G}\right)^{\alpha^{G}},
$$

where $K_{t}^{G}$ is public capital and $\alpha^{G}$ is the output elasticity with respect to public capital.

Private capital evolves by the law of motion 


$$
n k_{i t}^{N}=\left(1-\delta^{N}\right) k_{i t-1}^{N}+\left[1-\frac{\kappa^{N}}{2}\left(\frac{i_{i t}^{N}}{i_{i t-1}^{N}}-1\right)^{2}\right] i_{i t}^{N},
$$

where $\kappa^{N} \leq 0$ is the investment adjustment cost parameter.

A non-traded firm maximizes its net-present-value profit

$$
\begin{aligned}
& E_{t} \sum_{t=0}^{\infty} \beta^{t} \lambda_{t}^{a}\left(1-\tau^{k}\right) \times \\
& \underbrace{\left\{(1-\imath)\left[p_{i t}^{N} y_{i t}^{N}-\frac{\varsigma}{2}\left(\frac{\pi_{i t}^{N}}{\pi_{i t-1}^{N}}-1\right)^{2} p_{t}^{N} y_{t}^{N}\right]-w_{t}^{N} l_{i t}^{N}-i_{i t}^{N}+\imath p_{t}^{N} y_{t}^{N}\left[1-\frac{\varsigma}{2}\left(\frac{\pi_{t}^{N}}{\pi_{t-1}^{N}}-1\right)^{2}\right]\right\}}_{=\tilde{\Omega}_{i t}^{N}, \text { profit of firm } i},
\end{aligned}
$$

where $\lambda_{t}^{a}$ is the savers' marginal utility on consumption and $\pi_{t}^{N} \equiv \frac{P_{t}^{N}}{P_{t-1}^{N}}=\frac{p_{t}^{N}}{p_{t-1}^{N}} \pi_{t}$ is the inflation for nontradables. $\tau^{k}$ is the tax rate on corporate profits and is assumed constant over time. $l$ captures the distortionary factors in low-income countries that discourage firms from investing and hiring to achieve higher production. The after-tax profit of the non-traded sector is $\Omega_{t}^{N}=\left(1-\tau^{k}\right) \int_{0}^{1} \tilde{\Omega}_{i t}^{N} d i$.

A.2.2. Traded Good Sector. The traded sector is perfectly competitive and produces by the technology

$$
y_{i t}^{T}=z_{t}^{T}\left(k_{i t-1}^{T}\right)^{1-\alpha^{T}}\left(l_{i t}^{T}\right)^{\alpha^{T}}\left(K_{t-1}^{G}\right)^{\alpha^{G}} .
$$

The productivity $z_{t}^{T}$ includes learning-by-doing externalities, following the process

$$
\ln z_{t}^{T}=\rho_{z T} \ln z_{t-1}^{T}+d \ln y_{t-1}^{T} .
$$

The law of motion for capital is

$$
n k_{i t}^{T}=\left(1-\delta^{T}\right) k_{i t-1}^{T}+\left[1-\frac{\kappa^{T}}{2}\left(\frac{i_{i t}^{T}}{i_{i t-1}^{T}}-1\right)^{2}\right] i_{i t}^{T} .
$$

Like the non-traded good sector, $\kappa^{T}$ is the investment adjustment cost parameter. Each firm chooses labor, investment, and capital to maximize its weighted preset-value profits,

$$
E_{t} \sum_{t=0}^{\infty} \beta^{t} \lambda_{t}^{a}\left(1-\tau^{k}\right) \underbrace{\left[(1-\imath) s_{t} y_{i t}^{T}-w_{t}^{T} l_{i t}^{T}-i_{i t}^{T}+\imath s_{t} y_{t}^{T}\right]}_{\equiv \tilde{\Omega}_{i t}^{T} \text {, profit of traded firm } i} .
$$

The after-tax profit for the traded sector is $\Omega_{t}^{T}=\left(1-\tau^{k}\right) \int_{0}^{1} \tilde{\Omega}_{i t}^{T} d i$.

A.2.3. Natural Resource Sector. Assume the resource firm is a price taker in the relevant world commodity market. Let $P_{t}^{O *}$ be the world resource price in foreign currency. Its 
relative price to the foreign CPI is $p_{t}^{O *} \equiv \frac{P_{t}^{O *}}{P^{*}}$, and the relative price to the domestic CPI is $s_{t} p_{t}^{O^{*}}$. Because the current application of the model does not focus on fluctuations in resource revenue, it is assumed $p_{t}^{O *}=p^{O *} \forall t$. The model also abstracts from resource investment decisions and treats resource investment as exogenous. Given the foreign direct investment (FDI) in the resource sector $\left(i_{t}^{f *}\right)$, the total resource investment is $I_{t}^{O}=s_{t} i_{t}^{f *}$.

Capital in the resource sector evolves according to $n K_{t}^{O}=\left(1-\delta^{O}\right) K_{t-1}^{O}+I_{t}^{O}$. Output is produced by the technology $y_{t}^{O}=z^{O}\left(K_{t-1}^{O}\right)^{\alpha^{O}}$, where $z^{O}$ is the total factor productivity for the resource sector.

The government levies royalties (based on production) with a rate $\tau^{o}$. The resource sector's net profit in foreign currency is $\Omega_{t}^{O *}=\left(1-\tau^{o}\right) p_{t}^{O *} y_{t}^{O}$. In addition to taxes, the government also receives a share of resource dividends and interest income from the sovereign wealth fund $\left(F_{t}^{*}\right)$. Let $t^{d i v}$ be the dividend share that the government receives. The total resource revenue collected each period is

$$
T_{t}^{O}=s_{t}\left[\tau^{o} p_{t}^{O *} y_{t}^{O}+t^{d i v} \Omega_{t}^{O *}+\frac{\left(i^{*}-1\right) F_{t-1}^{*}}{n \pi^{*}}\right],
$$

where $\frac{\left(i^{*}-1\right) F_{t-1}^{*}}{n \pi^{*}}$ is the interest earned on the sovereign wealth fund.

A.3. The Public Sector. The government receives SACU transfers $s_{t} A_{t}^{*}$ in units of domestic composite consumption goods. The process of SACU transfers is modeled as exogenous and assumed to follow the process

$$
\log \frac{A_{t}^{*}}{A^{*}}=\rho_{a} \log \left(\frac{A_{t-1}^{*}}{A^{*}}\right)+\left(1-\rho_{a}\right) \log \left(\frac{A_{t-2}^{*}}{A^{*}}\right)+\varepsilon_{t,} \quad \rho_{a}>1 .
$$

The unit root process in the SACU transfers simulates a permanent SACU transfer shock $\varepsilon_{t}$, as analyzed in this paper.

Each period, the government's flow budget constraint is

$$
T_{t}+B_{t}-\left(D_{t}^{G}-\frac{D_{t-1}^{G}}{n \pi_{t}}\right)+s_{t} A_{t}^{*}+s_{t}\left(\frac{F_{t-1}^{*}}{n \pi^{*}}\right)=p_{t}^{G} G_{t}+Z_{t}+\left(i_{t-1}-1\right) \frac{B_{t}^{c}}{n \pi_{t}}+\frac{B_{t-1}}{n \pi_{t}}+s_{t} F_{t}^{*},
$$

where $B_{t}$ is total government debt outstanding, $B_{t}^{c}$ is government debt held by consumers, $D_{t}^{G}$ is government deposits at the central bank, $A_{t}^{*}$ is SACU transfers a country receives from South Africa, $G_{t}$ is government purchases, and $Z_{t}$ is total transfers to households. The total government receipts $T_{t}$ include taxes on labor income, corporate profits, and 
consumption, royalties and dividends from resource production, and the interest earned from the sovereign wealth fund:

$$
T_{t}=\tau_{t}^{c} C_{t}+\tau_{t}^{l} w_{t} L_{t}+\tau^{k}\left(\Omega_{t}^{N}+\Omega_{t}^{T}\right)+T_{t}^{O}
$$

Finally, government purchases $G_{t}$ consist of government consumption $\left(G_{t}^{C}\right)$ and government investment $\left(G_{t}^{I}\right)$. The law of motion of public capital is

$$
K_{t}^{G}=\left(1-\delta^{G}\right) K_{t-1}^{G}+e G_{t}^{I},
$$

where $e$ is government investment efficiency. Pritchett (2000) and Hurlin and Arestoff (2010) estimate the discrepancy between government investment costs and the value of constructed public capital. For low-income countries, $e$ is well below 1.

Government purchases are a CES basket that includes traded and non-traded goods,

$$
G_{t}=\left[v^{\frac{1}{\chi}}\left(G_{t}^{N}\right)^{\frac{\chi-1}{\chi}}+(1-v)^{\frac{1}{\chi}}\left(G_{t}^{T}\right)^{\frac{\chi-1}{\chi}}\right]^{\frac{\chi}{\chi-1}}
$$

where $v$ denotes the degree of home bias in government purchases. The relative price of government purchases to CPI is $p_{t}^{G}=\left[v\left(p_{t}^{N}\right)^{(1-\chi)}+(1-v)\left(s_{t}\right)^{1-\chi}\right]^{\frac{1}{1-\chi}}$.

A.3.1. Fiscal Policy. The analysis focuses on circumstances when the government does not engage in additional borrowing to make up the financing gap for its spending. Thus, it is assumed that the de-trended government debt is fixed over time at the steady state. When SACU transfers are reduced, the government is required to conduct fiscal adjustments to ensure that its budget is on a sustainable path. The analysis explores four fiscal adjustment strategies, and the policy rules that implement those strategies are described in Section II.B.

A.3.2. Reserve and Monetary Policy. Denote the government debt held by the central bank by $B_{t}^{c b}$ and the foreign reserve by $R_{t}^{*}$. The central bank's balance sheet is

$$
m_{t}-\frac{m_{t-1}}{n \pi_{t}}+D_{t}^{G}-\frac{D_{t-1}^{G}}{n \pi_{t}}=B_{t}^{c b}-\frac{B_{t-1}^{c b}}{n \pi_{t}}+s_{t}\left(R_{t}^{*}-\frac{R_{t-1}^{*}}{n \pi^{*}}\right) .
$$

The reserve policy follows the process

$$
\log \frac{R_{t}^{*}}{R^{*}}=\rho_{R} \log \left(\frac{R_{t-1}^{*}}{R^{*}}\right)+\omega \log \left(\frac{A_{t}^{*}}{A^{*}}\right)-\omega^{S} \log \left(\frac{\pi_{t}^{S}}{\pi^{S}}\right),
$$

where $\pi_{t}^{S} \equiv \frac{S_{t}}{S_{t-1}}$ and $S_{t}$ is the nominal exchange rate. $\omega^{S}$ indicates an exchange rate regime. Setting $\omega^{S}=0$ represents a flexible exchange rate regime. For a fixed exchange rate, $\omega^{S}$ is set to a large number like 500 or higher. 
The central bank can sterilize its monetary operation. Under full sterilization, the central bank adjusts the money aggregate to target the CPI inflation, and open-market operations imply that

$$
B_{t}^{c b}-\frac{B_{t-1}^{c b}}{n \pi_{t}}=\frac{m_{t-1}}{n \pi_{t}}\left[(1+\mu)\left(\frac{\pi_{t}}{\pi}\right)^{-\phi_{\pi}}-1\right]+D_{t}^{G}-\frac{D_{t-1}^{G}}{n \pi_{t}}-S_{t}\left(R_{t}^{*}-\frac{R_{t-1}^{*}}{n \pi^{*}}\right)
$$

where $\mu$ is the steady-state nominal money growth rate, and $\phi_{\pi}$ indicates the aggressiveness of the central bank toward stabilizing inflation.

If no full sterilization, then the central bank's bond holding adjusts according to inflation as

$$
B_{t}^{c b}-\frac{B_{t-1}^{c b}}{n \pi_{t}}=\frac{B_{t-1}^{c b}}{n \pi_{t}}\left[(1+\mu)\left(\frac{\pi_{t}}{\pi}\right)^{-\phi \pi}-1\right]
$$

By varying the weight (from zero to one) between the above two operations (A.24 and A.25), the model can be used to analyze fiscal adjustments under partial sterilization.

A.4. Aggregation and Account Identities. Let $X_{t}$ denote the aggregate quantity of a variable. Then, $X_{t}=f x_{t}^{a}+(1-f) x_{t}^{h}, \quad x \in\left\{c, c^{N}, c^{T}, m, l, r m^{*}, b^{*}, b^{c}\right\}$. The total government bonds corresponds to $B_{t}=B_{t}^{c}+B_{t}^{c b}$.

The current account deficit $\left(C A_{t}^{d}\right)$ corresponds to

$$
C A_{t}^{d}=\left[C_{t}+I_{t}+p_{t}^{G} G_{t}+\frac{\varsigma}{2}\left(\frac{\pi_{t}^{N}}{\pi_{t-1}^{N}}-1\right)^{2} p_{t}^{N} y_{t}^{N}\right]-p_{t}^{N} y_{t}^{N}-s_{t} y_{t}^{T}-s_{t} p^{O *} y_{t}^{O}-s_{t}\left(i^{*}-1\right) \frac{B_{t-1}^{*}+F_{t-1}^{*}}{n \pi^{*}}-s_{t} r m^{*},
$$

where $I_{t}=I_{t}^{N}+I_{t}^{T}+I_{t}^{O}$ is total investment in the private sector.

Last, the nominal GDP measured in the price of domestic consumption goods is

$$
Y_{t}=p_{t}^{N} y_{t}^{N}+s_{t} y_{t}^{T}+s_{t} p_{t}^{O *} y_{t}^{O}
$$

To calculate real GDP, each sector's output is evaluated at the original steady-state prices relative to the price of domestic consumption. 


\section{ApPendix II. CAlibration}

The model is calibrated to each of the four countries' economic structures and policies. Table 1 summarizes the common parameters across all countries.

Table 2 describes the steady state of each country before SACU transfer reductions and the country-specific parameters.

Table 1. Baseline Calibration

\begin{tabular}{lll}
\hline \hline parameters & values & notes \\
\hline$\sigma$ & 2 & inverse of intertemporal elasticity of substitution for consumption \\
$\psi$ & 2.5 & inverse of Frisch elasticity of labor supply \\
$\varphi$ & 0.6 & degree of home bias in consumption \\
$\chi$ & 1.5 & elasticity of substitution between traded and non-traded \\
$\theta$ & 12 & elasticity of substitution between non-traded goods \\
$\theta^{a}$ & 0.992 & preference weight on consumption for savers \\
$\theta^{h}$ & 0.828 & preference weight on consumption for the hand-to-nouth \\
$\kappa^{a}$ & 0.117 & preference weight on leisure for savers \\
$\kappa^{h}$ & 0.287 & preference weight on leisure for the hand-to-mouth \\
$\eta$ & 0.99 & implying that the interest elasticity of real money demand is 8.5 \\
$\delta$ & 0.84 & share of labor supplied to non-traded \\
$\rho$ & 1 & elasticity of substitution b/w the two types of labor \\
$\beta$ & 0.995 & the discount factor of savers \\
$\alpha^{T}, \alpha^{N}$ & 0.7 & share of labor income \\
$\alpha^{O}$ & 0.9 & resource production coefficient \\
$\alpha^{G}$ & 0.1 & output elasticity of public capital \\
$d, \rho_{Z T}$ & 0.1 & learning by doing \\
$\kappa^{N}, \kappa^{T}$ & 25 & investment adjustment cost \\
$\delta^{N}, \delta^{T}, \delta^{O}$ & 0.015 & depreciation rate for $K^{N}, K^{T}$ and $K^{O}$ \\
$\delta^{G}$ & 0.02 & depreciation rate for $K^{G}$ \\
$\varsigma$ & 130 & implying the marginal cost coefficient in the NK Phillips curve is 0.1 \\
$v$ & 0.7 & home bias of government purchases \\
$\rho_{a}$ & 1.5 & autoregressive coefficient in SACU transfers process \\
\hline & &
\end{tabular}


Table 2. Baseline Calibration

\begin{tabular}{|c|c|c|c|c|}
\hline Parameters & Botswana & Lesotho & Namibia & Swaziland \\
\hline Quarterly real output growth rate $n$ & 1.0103 & 1.0084 & 1.0099 & 1.0171 \\
\hline Quarterly domestic inflation $\pi$ & 1.0208 & 1.0168 & 1.0106 & 1.0181 \\
\hline Fraction of savers $f$ & 0.35 & 0.35 & 0.35 & 0.35 \\
\hline Production distortion $l$ & 0.48845 & 0.20025 & 0.29901 & 0.4507 \\
\hline Capital mobility $v$ & 500 & 500 & 500 & 500 \\
\hline Efficiency of government investment $e$ & 0.4 & 0.4 & 0.4 & 0.4 \\
\hline Resource GDP to GDP share & 0.1508 & 0.065 & 0.15 & 0.1 \\
\hline Steady-state effective labor tax rate $\tau^{l}$ & 0.1 & 0.1 & 0.08 & 0.1 \\
\hline Steady-state effective consumption tax rate $\tau^{c}$ & 0.1 & 0.1 & 0.1 & 0.1 \\
\hline Steady-state effective corporate tax tax rate $\tau^{k}$ & 0.15 & 0.15 & 0.12 & 0.15 \\
\hline Resource royalty rate on resource output $\tau^{o}$ & 0.001 & 0.001 & 0.02 & 0.001 \\
\hline Private consumption to GDP share & 0.7 & 0.771 & 0.54 & 0.771 \\
\hline Private investment to GDP share & 0.12 & 0.19 & 0.167 & 0.135 \\
\hline Mining value added to GDP share & 0.15 & 0.065 & 0.15 & 0.001 \\
\hline Government spending to GDP share & 0.35 & 0.475 & 0.36 & 0.214 \\
\hline Government consumption to GDP share & 0.2 & 0.453 & 0.251 & 0.164 \\
\hline Government investment to GDP share & 0.15 & 0.022 & 0.109 & 0.05 \\
\hline Traded government spending to GDP share & 0.105 & 0.19 & 0.108 & 0.0642 \\
\hline Non-traded government spending to GDP share & 0.245 & 0.285 & 0.252 & 0.1498 \\
\hline Trade balance to GDP share & -0.17 & -0.436 & -0.067 & -0.12 \\
\hline Non-traded value added to GDP share & 0.646 & 0.43388 & 0.466688 & 0.620944 \\
\hline Traded value added to GDP share & 0.204 & 0.50112 & 0.383312 & 0.378056 \\
\hline International reserves held by central bank to GDP Share & 0.162 & 0.48 & 0.089 & 0.199 \\
\hline SACU transfers/GDP*100 or Aid/GDP*100 before the reduction & 0.074 & 0.267 & 0.1 & 0.2 \\
\hline SACU transfers/GDP*100 in the new steady state (after the permanent reduction) & 0.024 & 0.2 & 0.05 & 0.05 \\
\hline$\rho^{g}$ & 0.9 & 0.9 & 0.9 & 1 \\
\hline Exchange rate regime $\omega^{S}$ & 1000000 & 1000000 & 1000000 & 1000000 \\
\hline
\end{tabular}

